\title{
8
}

\section{Device Physics in Organic Solar Cells and Drift-diffusion}

\section{Simulations}

Yuliar Firdaus, ${ }^{1 *}$ Thomas D. Anthopoulos ${ }^{1}$

${ }^{1}$ King Abdullah University of Science and Technology (KAUST), KAUST Solar Center (KSC), Thuwal 23955, Saudi Arabia

Keywords: Organic solar cells, device physics, drift-diffusion simulation

\subsection{Introduction}

Organic solar cell (OSC) devices have recently exceeded power conversion efficiencies (PCEs) of over $17 \%$ in single-junction cells [1-5] and a tandem device using nonfullerene acceptors (NFA) [6]. The device performances are still below the predicted efficiency limit of $20 \%$ and $25 \%$ for single-junction and tandem cells, respectively [7]. Improving the OSC device performance further required a detailed understanding of the underlying physical mechanisms and processes that make the device work, as well as those that lead to performance losses so that materials and device architectures can be further improved. Modeling can fulfill several 
tasks which range from theoretical discussions of physical mechanisms to the assistance in the interpretation of experiments. Unfolding the physics of these devices to create predictive physical models has been a challenging task due to the complexity of the employed materials and the device physics mechanisms.

The scope of theoretical studies is broad, including ab-initio studies,[8] Kinetic MonteCarlo (KMC),[9] and drift-diffusion models.[10] The techniques vary in the complexity of OSC description; therefore, the first task in the modeling is to determine how much detail is needed to capture the physical phenomena of particular process of interest. Microscopic modeling such as ab-initio and $\mathrm{KMC}$ calculations are typically expensive computationally speaking. As an alternative, a macroscopic technique such as drift-diffusion simulations that employ analytical effective-medium-approximation can capture the overall physical mechanisms at the device level. Drift-diffusion models can simulate a wide variety of OSC-device physics experiments, such as current-density-voltage (J-V) characteristics, photogenerated charge-extraction-bylinearly-increasing-voltage (photo-CELIV), transient photo-current (TPC), and time-delayed collection field (TDCF) measurements.[11-18]

In this chapter, after a discussion of the fundamental physical mechanisms in the OSC device operation, we discuss a brief description of drift-diffusion simulations and its implementation. We then highlight examples where drift-diffusion methods have been used to understand and optimize OSCs. In the end, we provide a summary and outlook on the device simulation with recommendations for directions of future research. 

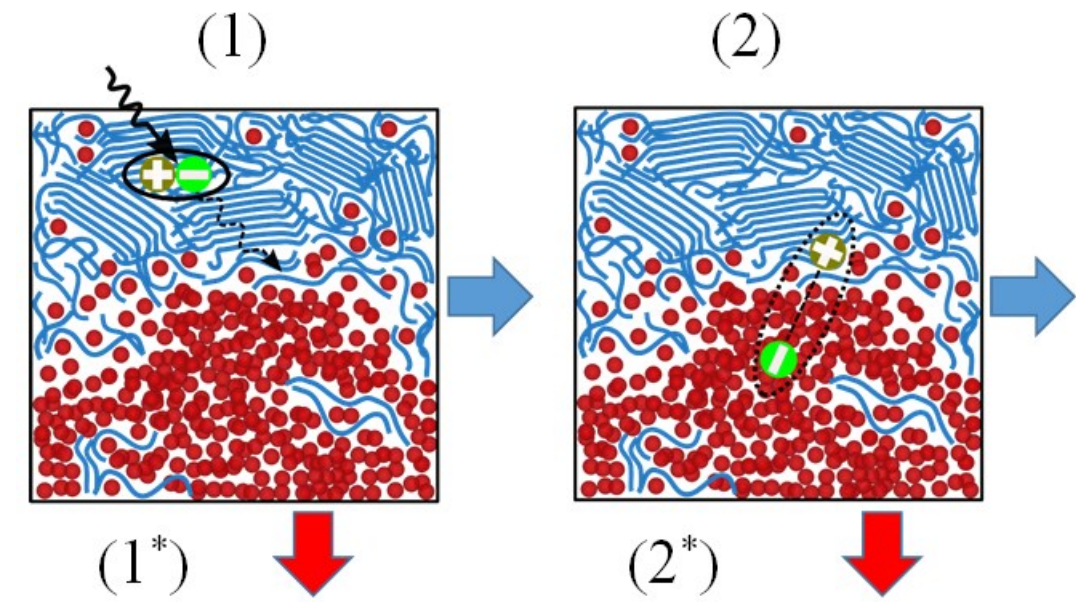

(3)
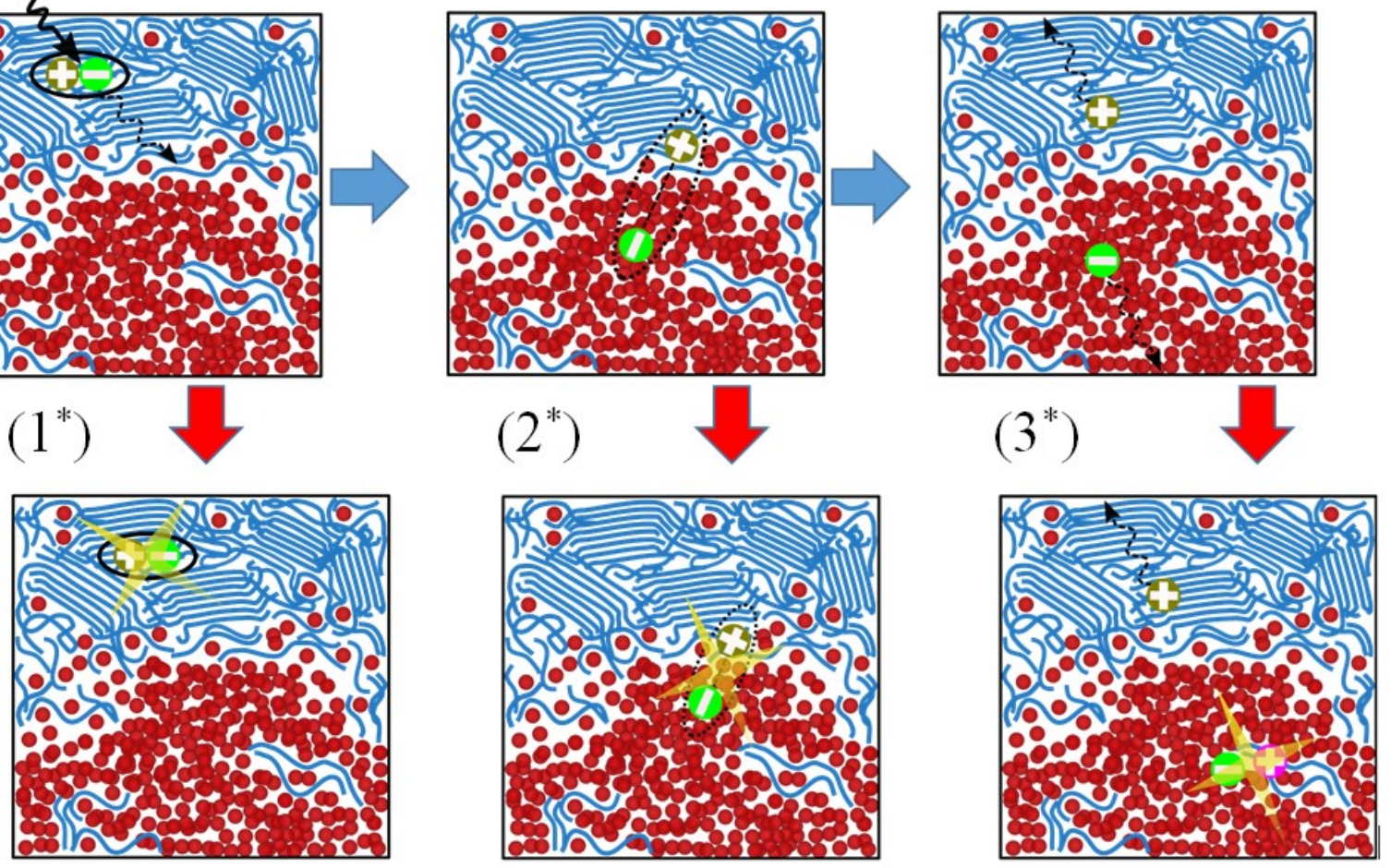

Fig 8.1. Device physics in BHJ OSC covering photocurrent generation (blue arrow): (1) photoexciton generation in the donor or acceptor followed by exciton diffusion; (2) ultrafast charge transfer (CT) at the interface; (3) charge separation followed by charge transport and extraction at the electrodes. Possible photocurrent loss (red arrow) also shown: $\left(1^{*}\right)$ exciton recombination; $\left(2^{*}\right)$ geminate recombination of CT states; $\left(3^{*}\right)$ nongeminate recombination of free charges (between opposite charges generated from different excitations).

\subsection{Fundamental processes in OSCs}

In brief, the physical processes occurring in bulk-heterojunction (BHJ) solar cells is now commonly believed to involve (Fig 8.1):[19] (1) photoexcitation of the BHJ creates tightly bound Frenkel-type singlet excitons followed by transport of the excitons to donor-acceptor (DA) interface;[20] (2) the excitons dissociate at the DA interface, which in highly mixed blends leads to ultrafast femtoseconds (fs) exciton quenching while in the case of large-scale DA demixing, diffusion of excitons takes place on the timescale of several picoseconds (ps);

(3) exciton quenching by interfacial charge transfer eventually leads to the formation of interfacial charge-transfer (CT) states and spatially-separated (free) charge carriers.[21] After 
charge separation, the electron and hole are transported through the respective materials and collected by the electrodes, resulting in a photocurrent in the external circuit. The CT states generated upon charge transfer at the interface may not dissociate entirely into free charges if the charges cannot overcome their mutual Coulomb attraction. These CT-states recombine geminately, typically on the timescale of hundreds of picoseconds to several nanoseconds. Additionally, the free charge carrier extraction often competes with nongeminate recombination, potentially leading to low fill factors (FFs). Both geminate and nongeminate recombination contribute as loss channels, reducing the quantum efficiency of the solar cell.

\subsection{Exciton transport}

Due to the low dielectric constant of organic semiconductors, excitons have a relatively large binding energy and relatively localized. To overcome the exciton-binding energy and efficiently generate free charge carriers, efficient OSCs use a blend of DA that phase-separate to form a BHJ structure.[22] The utilized DA creates an energetic driving force for exciton dissociation into a CT state at the DA interface. Photogenerated excitons must reach a DA interface before returning to the ground state to generate charges. The DA heterojunctions for separating bound excitons into free charge pairs require distribution on a comparable length scale to the exciton diffusion length, which limits the maximum domain size of the BHJ structure. If DA domains are too large (in comparison to exciton diffusion length), too many excitons generated in the interior of the domains cannot reach an interface for dissociation. If domains are too small, the charge transport and collection are compromised. The diffusion length scale of singlet exciton is typically 5-10 $\mathrm{nm}$ for the majority of amorphous materials,[23] which introduces a trade-off between exciton harvesting and subsequent charge collection efficiencies in BHJ OSC.

An exciton can move between molecules via a non-radiative process of energy transfer, which might occur via Förster or Dexter mechanisms.[24-26] The Förster transfer can occur through space (long-range) via dipole-dipole electromagnetic interaction and requires a 
significant overlap of emission and absorption spectra of the molecules.[23] Dexter mechanism, which often used to describe triplets excitons, occurs via an actual exchange of electrons between "donor" molecule and "acceptor" molecule with distance only about $1 \mathrm{~nm}$ apart.[23] Since Förster energy transfer is much more critical in singlet exciton diffusion, Förster resonance energy transfer (FRET) theory often utilized to describe the diffusion.[27] The conventional FRET theory, where point dipoles can approximate the molecules, has been successfully applied to predict the diffusion length of small molecules.[28, 29] On the other hand, in conjugated polymer films, diffusion dynamics are more complicated and significantly depends on energetic, spatial, and orientation disorders.[30]

The inherent disorder present in conjugated polymers largely determines physical processes related to exciton diffusion. Mikhnenko et al.[31] reported an interesting study of exciton diffusion in conjugated polymers. The exciton dynamics reveal two temperature regimes: At low temperature (e.g., $<150 \mathrm{~K}$ ), the exciton diffusion length (coefficient) is nearly temperature independent while increasing the temperature up to $293 \mathrm{~K}$ leads to a gradual growth up. They argue that two processes govern the exciton diffusion in conjugated polymers: an initial downhill migration toward lower energy states in a broad density of states, followed by temperature-activated hopping which switched off below $150 \mathrm{~K}$.

The diffusion length, $L_{\mathrm{D}}$ is given by $\sqrt{Z D \tau}$, where $D$ is the diffusion coefficient, $\tau$ is the exciton lifetime, and $\mathrm{Z}$ is equal to 1,2 , or 3 in the case of one-, two- or three-dimensional diffusion, respectively.[23] The lifetime of the singlet exciton in most conjugated polymer films and the small molecule is short, typically in the range of several hundred picoseconds, since the lifetime intrinsically link with the transition dipole moment (which varies little for strongly absorbing $\pi$-conjugated materials). The exciton lifetime also found to be suppressed via nonradiative relaxation in low bandgap materials.[32] Yosh et al.[33] performed a theoretical study of singlet and triplet diffusion by ab-initio means. They showed that it is difficult for singlets to increase the diffusion coefficient without decreasing the lifetime and hence creates 
a fundamental upper bound on the diffusion length (e.g., $100 \mathrm{~nm}$ for tetracene). On the other hand, for triplets, the lifetime and diffusion coefficient can be varied independently; hence there are no corresponding limits.

Menke et al.[34] showed that singlet exciton diffusion length in the subphtalocyanine derivative could increase by suppressing the non-radiative decay rate. In many cases, materials with a higher degree of order of crystallinity show higher singlet diffusion length. Lunt at al.[35] showed that exciton diffusion length in 3,4,9,10-perylenetetracarboxylic dianhydride (PTCDA) is increased from 6 to $20 \mathrm{~nm}$ when the average diameter of crystalline domains enhanced from 100 to $400 \mathrm{~nm}$. The extent of crystalline order of PTCDA thin films was varied using a range of vapor phase growth condition. Chemical modifications,[36-38] or thermal annealing[39-42] could modify different degrees of crystallinity and diffusion length. In general, very long diffusion lengths have only been reported in conjugated polymer nanofiber $(>200 \mathrm{~nm}),[43]$ small molecule J-aggregates $(96 \mathrm{~nm}),[29]$ or organic single-crystals $(>1 \mu \mathrm{m})$.[44]

\subsection{Charge separation}

If a singlet exciton reached the DA interface, the charge transfer occurs only when considerable binding energy of the singlet exciton is overcome by electron transfer to an energetically favorable acceptor molecule.[45-47] At the DA interface, a fraction of electrons and holes escape their Coulomb attraction and split into free charges. The interfacial electron-hole pairs that have relaxed into CT states and could not overcome the Coulomb binding energy may recombine in a process commonly referred to as geminate recombination. Geminate recombination occurs when a hole and electron that originate from the same photon recombine before separating into free charges. Note that it's also has been shown in the case NFA-based blends that energy transfer from the donor molecule to the acceptor molecule occur, which followed by hole transfer from the acceptor molecule the donor molecule.[12] 
There have been debates on the intermediate states involved in the conversion of excitons into free charge carriers. $[20,48]$ There exist several viewpoints as to what happens after the charge transfer at the DA interface. The first viewpoint is that during the charge separation process, electron and hole are still correlated and coulombically bound (intermediate CT state). The bound state then needs to overcome the binding energy to create fully separated charge carriers. The energy required to overcome the Coulomb potential binding was first described by Onsager[49] and Braun[50]. Marsh et al.[51] in 2010 showed a direct measurement of electric field-assisted charge separation in polymer:fullerene solar cells using transient absorption (TA) spectroscopy. Similar outcome of field-dependent carrier dissociation has also been reported earlier by Veldman et al.[52] in 2008. In the second viewpoint, the chargeseparated states directly create fully separated and unbound charge carriers. Guo et al.,[53] Jamieson et al.,[54] and Howard et al.[55] show evidence for field-independent ultrafast charge separation obtained from the intensity or field-dependent TA spectroscopy measurements. Transient photoconductivity experiments from several groups have shown that free carrier generation is field independent in efficient BHJ blend devices and thin films. $[18,56]$ Recent evident points to a newly developing viewpoint that primary excitations have two coexists paths (intermediate CT state and direct free charge generation) to free carriers. Etzold et al.[57] performed TA measurements in efficient BHJ blend systems-P3HT:PCBM and PCDTBT:PCBM- from 100 fs to $1 \mathrm{~ms}$ (short and long delays). Using a time-dependent analytical model, they were able to quantify ground state (GS) population, bound CT state population, and spatially separated carrier population and decay processes (geminate and nongeminate decay). They infer that $89 \%(85 \%)$ of carriers in the PCDTBT:PCBM (P3HT:PCBM) blend film charge separate on the ultrafast time scale, and only $11 \%(15 \%)$ of carriers pass through $\mathrm{CT}$ states to recombine geminately. Their results conclude that $\mathrm{CT}$ states play a minimum role in charge dissociation for efficient BHJ OSCs. 
Previous works have also suggested that there is a threshold in the energy offset of energy levels between donor and acceptor material to have the transition from singlet to CT state.[58, 59] This driving force results in energy loss due to the difference in energy of the donor singlet excited state and the CT state, which for fullerene-based OPV is typically around $0.2-0.3 \mathrm{eV}$ in the best cells.[60] While it was initially believed to be an intrinsic problem of OSC, recent development in NFAs has shown that ultrafast and efficient charge separation is possible even for zero electron-affinity (EA) or ionization energy (IE) offsets,[61-63] contrary to fullerenebased systems. Moreover, the negligible driving forces are often used to explain low energy losses in high-performing NFA blends.[61, 64] Very recently, barrier-less dissociation has been demonstrated in the high-performance blend of the donor polymer PM6 with the NFA Y6.[65] This fact motivates a re-examine of the charge separation process and mechanism. Yao et al.[66] comparing the electrostatic potential (ESP) of polymer donor, IT-4F NFA, and $\mathrm{C}_{60}$. They found that the donor has a net negative ESP, while for the NFA, large parts of the surface have a positive ESP. This condition favors exciton dissociation and electron transfer from donor to acceptor. For comparison, fullerene acceptor $\mathrm{C}_{60}$, exhibits a homogeneous and more neutral ESP allowing only weak interaction for charge separation. On the contrary, a few recent studies recognize that IE offsets might be necessary for charge generation.[67-69] Therefore, a coherent study on this topic, and a uniform characterization of a large NFA series are still missing.

\subsection{Charge Transport}

Once electron-hole pairs form charge-separated states (free charges), the internal electric field in the device drives it towards the electrodes. Electron drift toward the cathode, and holes drift to the anode. In this process, charge transport in the organic semiconductor is fundamental to the operation of OSC devices. In OSCs, high and balanced charge transport reduces current losses from recombination.[70] The charge motion in disorder organic molecules occurs by 
hopping between distinct localized states on different molecules. Efficient charge transport requires that the charges be able to "hop" between molecules and not be trapped or scattered. Therefore, many factors such as molecular packing, disorder, presence of impurities, temperature, electric field, charge-carrier density, and size/molecular weight influence charge transport.[71] For a more straightforward description specifically on applications, charge mobility has been used as a parameter to benchmark and compare different organic material. Charge carrier mobility in organic semiconductors predicted to be similar for electron and holes for most materials.[71] However, experimentally organic semiconductors often exhibit highly unipolar charge transport, which means that they are predominantly transporting one carrier. For example, hole transport is dominant in most solution-processed conjugated polymers, with orders of magnitude higher than electron transport. By systematically investigate polymers with different electron affinity, Nicolai et al.[72] found that electron trapping in bulk is the reason for the low electron mobilities in those polymers. The trap depth reduces with increasing EA, suggesting the presence of a general impurity acting as the electron trap, with an EA of around 3.6 eV. For this reason, polymers with EAs higher than $3.6 \mathrm{eV}$ can exhibit trap-free electron transport, a design rule for the realization of n-type conducting polymers. Kotadiya et al.[73] further generalize this concept of electron trapping for organic semiconductors by including transport measurements on vacuum-deposited small-molecules. They demonstrated that not only electron transport becomes trap-limited when the EA is below $3.6 \mathrm{eV}$, but also hole transport will be limited by trapping when the IE of the material exceeds $6 \mathrm{eV}$, implying the observation of trap free charge transport only within this energy window (Fig 8.2). 


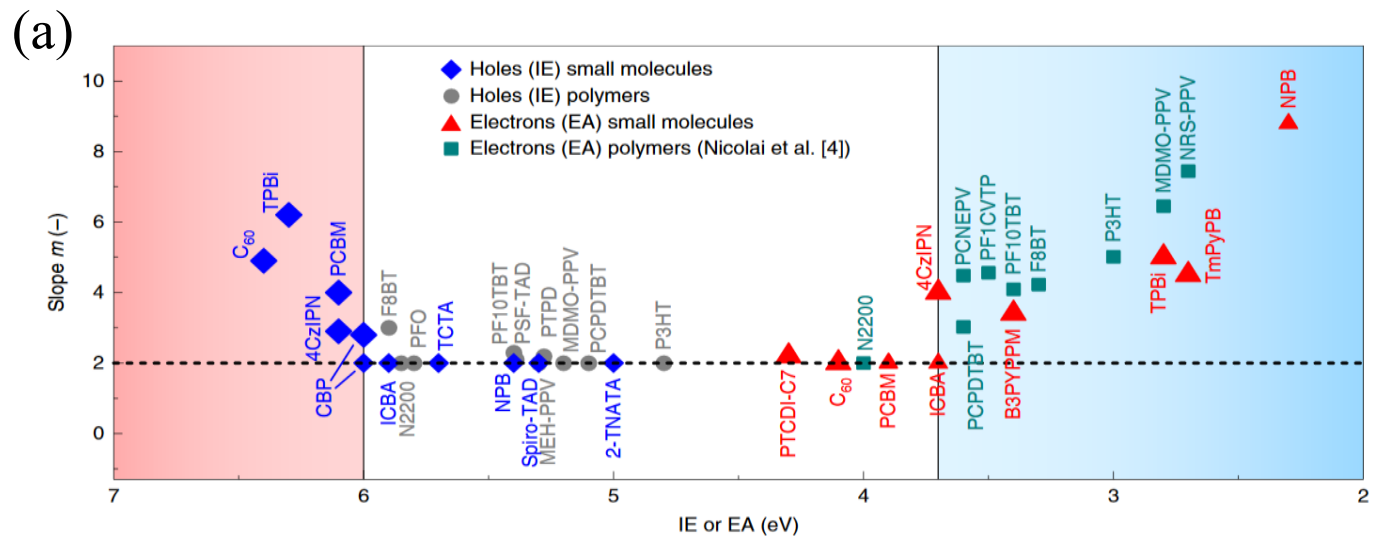

(b)

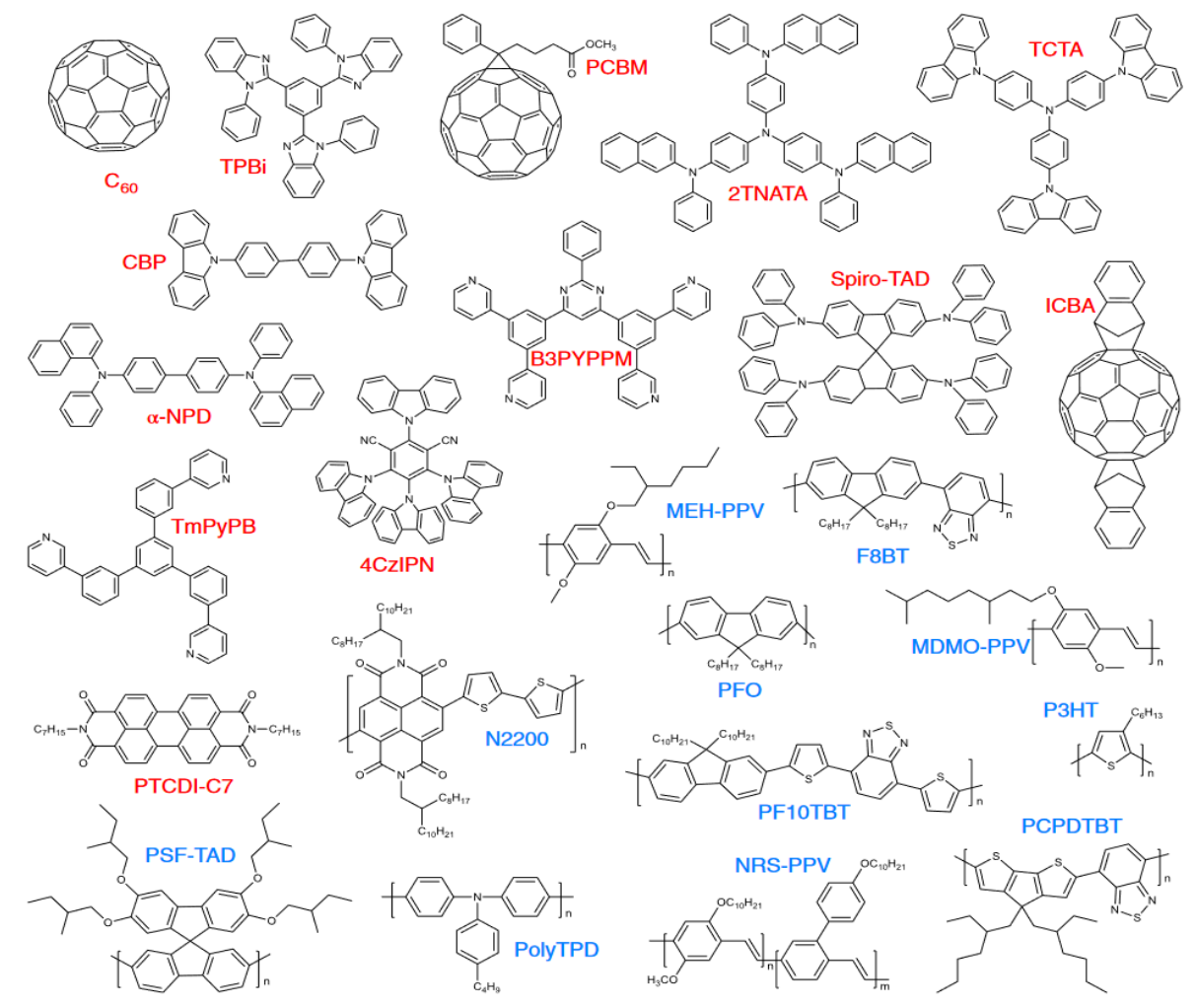

Fig 8.2. Energy window for trap-free charge transport. (a) The slope of the hole or electron current versus IE or EA of the organic semiconductor, respectively. The symbols are divided into groups representing either electron or hole transport in either small molecules or polymers. The dashed line marks a slope of two, characteristic of a trap-free space-charge-limited current. Trap-limited currents $(\mathrm{m}>2)$ for electrons and holes are marked by the blue and red shaded areas, respectively. (b) The chemical structures of the investigated molecules. Reprinted with permission from Kotadiya et al., Nat. Mater., 2019, 18, 1182. Copyright (C) 2019, Springer Nature.

While many works focused on the charge transport in neat organic films, it is especially critical to know about the charge transport in the complex BHJ blend. Many SCLC measurements of materials used for OSCs showed that the BHJ blend film's mobilities are lower than in the neat film.[74-77] Measurement from photoconductive atomic-force-microscopy 
(AFM) showed that the local photocurrent might not be uniform throughout the blend film.[78] Frost et al.[79] used a Monte Carlo calculation to study the effect of morphology on charge transport and found that morphology strongly influences charge-transport characteristics, such as percolation threshold, mobility, charge dispersion. Similarly, Groves et al.[80] showed that local changes in the blend morphology could lead to local changes in the mobility by more than an order of magnitude. Koster found that using a master-equation calculation, the dependence of mobility on charge carrier concentration is more pronounced in blends, and influenced by the electric field strength.[81] At low charge carrier densities, blend mobility is found to decrease with increasing field. Further calculation from Heiber et al.[82] using the KMC approach showed that the electric-field dependence of the charge-carrier mobility in a BHJ blend is profoundly affected by the tortuosity.

\subsection{Charge Recombination}

During charge transport to the electrodes, free electrons and holes can encounter and recombine. This recombination is known as nongeminate recombination since the recombining charge carriers originate from different photoexcitations. The rate of nongeminate recombination, $R$, depends on both carrier concentration $n$ (or $p$ ) and the effective carrier lifetime $\tau(n)$. Based on this rate, the recombination originating from these nongeminate charge carriers can be divided into three different mechanisms: trap-assisted (monomolecular, $R_{\mathrm{SRH}} \sim n$ ), $\operatorname{bimolecular}\left(R_{\mathrm{L}} \sim n p\right)$, and auger (trimolecular, $\left.R_{\mathrm{A}} \sim n p n\right)$ ).[83] Although trap-assisted recombination involves two carriers, it is still considered monomolecular recombination because it involves one free carrier and one oppositely charged trapped carrier. The recombination rate is ultimately determined by the amount of sites that act as traps and by how quickly the free carrier can find the trapped carrier. Reducing the trap density in the BHJ layer with p-type dopant or n-type dopant such as 2,3,5,6-Tetrafluoro-7,7,8,8-tetracyanoquinodimethane (F4-TCNQ) or benzyl-viologen (BV) has been demonstrated which reduce trap-assisted recombination and enable an increase in the 
FF of OPVs.[2, 84] Next, bimolecular recombination is the most commonly observed in OSC devices which involve the recombination of a free electron with a free hole.[85] For most stateof-the-art OSC, the nongeminate recombination with this mechanism is the dominant lossmechanism. The simplest description of bimolecular recombination is Langevin's model.[10, 86] In this model, the Coulomb attraction between electrons and holes results in recombination rate of $R=\frac{e}{\varepsilon_{r} \varepsilon_{0}}\left(\mu_{e}+\mu_{h}\right) n p$. In Auger recombination, an electron in the LUMO recombines with a hole in the HOMO after which the energy is transferred to a third electron which is then excited to a higher energetic state.[83] Although there have been a few reports of a recombination mechanism with a third-order dependence on carrier density in P3HT:PCBM solar cells devices,[87-89] it is generally not believed to be due to Auger recombination. Requirement for Auger recombination is a high charge density and so far this mechanism only established in inorganic semiconductors.[83]

Moreover, the carrier density dependence of the nongeminate recombination rate, or referred to as the order of recombination, often observed experimentally to be higher than that predicted by Langevin's model, which is a power-law decay rate, $R \sim n^{\lambda+1}$.[88] Shuttle et al.[88] suggested that a third-order dependence of recombination rate on charge density is likely related to a bimolecular recombination process in which the corresponding bimolecular recombination coefficient is carrier dependent $(k(n))$ rather than a trimolecular process. It has been shown also in pristine organic materials carrier transport at room temperature is mostly governed by carrier density.[90] Previous finding also shows that the carrier density is heavily influenced by carrier diffusion from the contacts.[91] Kirchartz and Nelson further suggested that spatial distribution of charge density is susceptible to active-layer thickness.[92] They further show that, for active layer thicknesses below $100 \mathrm{~nm}$, the recombination order starts to increase strongly due to the large gradient in carrier concentration. Therefore, the higher recombination orders at least in part originate from spatial gradients of the carrier density and the carrier density dependence of 
the mobility, $R \sim \mu_{\text {eff }}(n) n^{2}$. Other effects influencing the recombination order include injection of majority carriers by electrodes with small injection barriers[93] and doping[94].

Another critical discussion regarding the charge recombination is its adverse effect on energy loss in OSCs. Apart from the energy loss due to the charge generation process occurs via an interfacial $\mathrm{CT}$ state $\left(\Delta E_{\mathrm{CS}}=E_{\mathrm{g}}-E_{\mathrm{CT}}\right)$, OSCs also exhibit additional energy loss. This second part of the loss expressed as $E_{\mathrm{CT}}-e V_{\mathrm{OC}}$ is often found to be typically between $0.5-0.7 \mathrm{eV}$ in fullerene-based OPV.[95] This energy loss is made up of two contributions:[96] (1) radiative loss, which is thermodynamically unavoidable, and (2) non-radiative loss incurred during charge separation and transport. Therefore, one possible avenue to reduce energy loss is by reducing the non-radiative decay pathways significantly. Ran et al.[97] have shown that nonradiative recombination is a function of molecular orientation at the DA interface, with face-on interfaces losing less voltage to non-radiative recombination than edge-on interfaces. Liu et al.[61] also have shown that the energy loss due to recombination $\left(E_{\mathrm{CT}}-e V_{\mathrm{OC}}\right)$ in NFA-based OSC can be as low as $0.33 \mathrm{eV}$ with the loss due to non-radiative recombination is around 0.26 $\mathrm{eV}$.

\section{Macroscopic drift-diffusion simulation}

Drift-diffusion models express the flow of populations of charges in terms of drift and diffusion components. Drift is the average motion of charges subjected to an electric field component and expressed using the concept of carrier mobility. Diffusion is a random thermal motion of charges due to a concentration gradient of carriers. The drift-diffusion system of equations is a simplification of the Boltzmann-transport equation. The models have been utilized for organic light-emitting diodes,[98] field-effect transistor,[99] and bilayer OSCs[100]. Koster et al.[10] in 2005 used the models to examine the J-V of polymer:fullerene BHJ OSCs. The models allow $\mathrm{J}-\mathrm{V}$ simulations of multilayer devices consisting of complicated structures when combined with the transfer-matrix method.[101] One-dimensional (1D) drift-diffusion simulations are an 
effective-medium approach which means that all position acts as a donor and acceptor site simultaneously. On the other hand, the approach provides a trade-off between physical depth and computation cost. Moreover, multidimensional drift-diffusion simulations could include the effect of morphology, which will be discussed in Section 4.2.

As described in reference [10, 102], the set of equations used in $1 \mathrm{D}$ drift-diffusion simulation are:

1. Electron $(n)$ and hole $(p)$ continuity equations, describing the current transport, generation rate, and recombination of free charge carriers:

$$
\begin{gathered}
\frac{\partial n}{\partial t}=\frac{1}{q} \nabla J_{n}(x)-\sum_{i} R_{i}(x)+\sum_{j} G_{j}(x) \\
\frac{\partial p}{\partial t}=-\frac{1}{q} \nabla J_{p}(x)-\sum_{i} R_{i}(x)+\sum_{j} G_{j}(x)
\end{gathered}
$$

where $q$ stands for the elementary charge, $n(x), p(x)$ for the electron/hole density, $J_{\mathrm{n}}\left(J_{\mathrm{p}}\right)$ is the electron (hole) current density. The equations account for all possible generation and recombination loss mechanisms for the electron and hole densities, given by $n$ and $p$, respectively. The current density gradient term $\left(\nabla J_{n, p}\right)$ accounts for any local-current imbalance, which may lead to either accumulation or depletion of charge density. This term can, therefore, function as either a gain or loss mechanism of carrier density, depending on the local environment. The $G$ term represents the free carriers generation via exciton dissociation events following the absorption of photons. The $R$ term represents the loss rate of charges due to recombination events and is usually a function of electron and hole density.

2. The electron and hole currents described by the drift-diffusion equations:

$$
\begin{aligned}
& J_{n}(x)=q n(x) \mu_{n} E(x)+q D_{n} \nabla n(x) \\
& J_{p}(x)=q p(x) \mu_{p} E(x)+q D_{p} \nabla n(x)
\end{aligned}
$$


where $\mu_{\mathrm{n}}, \mu_{\mathrm{p}}$ stand for electron and hole mobilities, $E(x, t)$ is electric field, $D_{\mathrm{n}}\left(D_{\mathrm{p}}\right)$ is the electron (hole) diffusion coefficient.

3. The electric field $E$ is calculated according to the Poisson equation:

$$
\nabla E(x)=-\frac{q}{\varepsilon_{r} \cdot \varepsilon_{0}}(n(x)-p(x)+C)
$$

where $\varepsilon_{\mathrm{r}}$ is the relative dielectric constant, $\varepsilon_{0}$ is the vacuum permittivity constant, and $\mathrm{C}$ is the doping concentration.

4. The unique solution to the system of equations (1)-(5) can be obtained by specifying the boundary condition for carrier densities and potential at both contacts. For example, Koster et al.[10] assumed both contacts to be Ohmic and the boundary condition for the electric potential, $\psi($ with $E=\nabla \psi)$ :

$$
\psi(L)-\psi(0)=E_{g a p}-V_{a p p}
$$

The set of equations (1) to (5) can be solved numerically. A variety of approaches have been developed for the numerical calculation. The calculation starts from an initial guess of charge densities and potentials at each grid point in $x$. The potentials then improved using the iterative Gummel[103] method. Then charge densities are recalculated with the process repeated until a self-consistent solution for potential and charge density is obtained. The current then can be calculated. For the 1D drift-diffusion, the equations are discretized for use on a 1D spatial grid, where each node has a specific electric potential $\psi_{i}$. Scharfetter-Gummel's approach often used to decouple the Poisson equation from the continuity equations.[104] 


\section{Modeling Organic Photovoltaics}

\subsection{Charge Generation, and Recombination}

The right-hand side of equation (1) describes the net generation rate of free charges. The third term in brackets describes the rate at which free photo-generated charges are created, which can be expressed as $G(x)=G_{\mathrm{opt}}(x) \eta_{\mathrm{ED}} P(x)$. Here, $G_{\mathrm{opt}}(x)$ is the local rate of photon absorption (e.g., simulated by transfer-matrix calculation[101]), $\eta_{\mathrm{ED}}$ is the efficiency with which excitons dissociate, and $P(x)$ is the local efficiency with which geminate pairs separate into free charges. The second term in brackets, $R(x)$, is the local rate at which free charges recombine nongeminately.

As described in Section 2.1, the traditional view after being photogenerated, the excitons will diffuse from the created locations to the DA interfaces. Note that only singlet excitons are considered in the diffusion and dissociation processes since triplet excitons are more difficult to dissociate.[105] In contrast, charge separation from the exciton delocalization has been confirmed as well by several groups.[47, 106-108]

If geminate recombination does not occur in a particular OSC, then $P(x)=1$ and the field dependence of photocurrent in an OSC is mainly governed by bimolecular recombination, $R(x) .[7,11-13,109]$ However, when geminate recombination does occur, the most common way of representing $P(x)$ is using the so-called Onsager-Braun model. Alternative to the Onsager-Braun model, other formulations of $\mathrm{P}(\mathrm{x})$ have also been developed, such as the model with finite recombination rate,[110] and model which include energetic disorder with an exponential DOS.[111]

The Onsager-Braun model initially discussed by Onsager,[49] and refined by Braun,[50] proposed that the probability of exciton dissociation depends on the temperature, distance, and field 


$$
p(x, E, T)=\frac{k_{d}(x, E, T)}{k_{d}(x, E, T)+k_{f}(T)}
$$

where $T$ is the temperature, $x$ is the distance between the bound charges of the exciton, $E$ is the internal electrostatic field, and $k_{\mathrm{f}}$ is the exciton decay rate, which equals to $1 / \tau_{\mathrm{f}}$, and relates to the geminate recombination. Braun derives the following expression for dissociation rate $k_{\mathrm{d}}$ :

$$
k_{d}(x, E, T)=\frac{3 R}{4 \pi a^{3}} e^{-\frac{E_{B}}{k T}} J_{1}(2 \sqrt{-2 b}) / \sqrt{-2 b}
$$

where $E_{B}=q^{2} / 4 \pi \varepsilon_{\mathrm{r}} \varepsilon_{0} x$ is the exciton binding energy, $J_{1}$ is the first-order Bessel function, $R$ is bimolecular recombination rate, $a$ is the charge-separation distance, and the field parameter $b=q^{3} E /\left(8 \pi \varepsilon_{\mathrm{r}} \varepsilon_{0}(k T)^{2}\right)$. The exciton dissociation probability in equation (7) is field dependent, hence the field-dependence of photocurrent in OSCs when geminate recombination is present is due to both geminate and bimolecular recombination.

Recently, Wang et al.[112] reported a modified drift-diffusion model where two different physical processes generate the free carriers: direct generation through the delocalization and indirect generation through the diffusion and dissociation. The two processes were treated separately. The electron current continuity equation, for example, expressed as:

$$
\frac{\partial n}{\partial t}=\frac{1}{q} \nabla J_{n}(x)-\sum_{i} R_{i}(x)+\sum_{j} G_{j}(x)+k_{d} X_{l}
$$

where $X_{1}$ is the density of localized singlet excitons. The basic governing equation for localized excitons is given by

$$
\frac{\partial X_{l}}{\partial t}=\eta_{s} \sum_{i} R_{i}(x)+\left(1-\eta_{d}\right) \sum_{j} G_{j}(x)-k_{d} X_{l}-\frac{X_{l}}{\tau_{f}}+\nabla \cdot\left(D_{X} \nabla X_{l}\right)
$$


where $1-\eta_{\mathrm{d}}$ is the exciton localization ratio, $D_{\mathrm{X}}$ is the localized exciton diffusion coefficient, $\tau_{\mathrm{f}}$ is the lifetime of a single exciton, and $\eta_{\mathrm{s}}$ is the free carrier recombination ratio.

They further treat the charge-separation distance as a Gaussian distribution, and the overall exciton dissociation probability comes from the integral average over all the charge-separation distances

$$
p(x, E, T)=\frac{4}{\sqrt{\pi a^{3}}} \int_{0}^{\infty} p(x, E, T) x^{2} e^{-\left(\frac{x}{a}\right)^{2}} d x
$$

where $a$ is the charge-separation distance at the maximum probability of Gaussian function, which is also regarded as the exciton radius, while exciton dissociation rate is expressed as

$$
k_{d}(x, E, T)=\frac{p(E, T)}{1-p(E, T)} k_{f}(T)
$$

With this model, they showed that the increase of the exciton delocalization ratio simultaneously improve $J_{\mathrm{SC}}, V_{\mathrm{OC}}, \mathrm{FF}$, and PCE of the OSC devices and the enhancement of the delocalization ratio by optimizing the BHJ structure is essential to the performance of OSC.[112]

Returning to equation (1) and (2), the bimolecular recombination rate, $R(x)$, as discussed in Section 2.4 often described to be diffusion-limited, or Langevin-type, bimolecular recombination and defined as:

$$
R(x)=\beta\left(n p-n_{i}^{2}\right)
$$

Here $n_{\mathrm{i}}$ is the intrinsic charge carrier density due to thermal excitation across the diagonal bandgap. The recombination prefactor is initially given by the Langevin expression[86]

$$
\beta=\frac{q}{\varepsilon_{r} \varepsilon_{0}}\left(\mu_{n}+\mu_{p}\right)
$$


where $\varepsilon_{\mathrm{r}} \varepsilon_{0}$ is the material dielectric constant, and $\mu_{\mathrm{n}, \mathrm{p}}$ are the electron and hole mobilities. In BHJ OSCs, deviations from Langevin's recombination have been observed.[7, 11-13, 70, 113] Therefore, reduction factor (or termed as reduced Langevin recombination) often need to be taken into account in the drift-diffusion simulation by multiplying Langevin's recombination rate by a prefactor varying typically between $10^{-3}$ to $10^{-1}$, depending on the material system. The reduced Langevin recombination has been explained by the inherent property of phaseseparated BHJ structure,[114] the Langevin recombination constant dominated by the slowest charge carrier,[115] the presence of charge carrier concentration gradients,[116] spatial localization of recombination zones to DA interfaces.[117] The most prominent explanation for reduced Langevin recombination is that in some BHJ blends the recombination process is not encounter-limited but reaction-limited, where charge carriers can meet at the DA interface and then re-dissociate to form free charge carriers again.[21, 118]

The bimolecular recombination can also occur via a trap state (trap-assisted) somewhere in the bandgap and known as Shockley-Read-Hall recombination. With this recombination, holes or electrons are firstly trapped within the bandgap and then recombine with an oppositely charged carrier. The rate for this process in equilibrium when the Fermi level coincides with the electron-trap energy is given by [119] and can be included to the drift-diffusion calculation into the term $R(x)$ in equation 1 :

$$
R(x)=\frac{C_{n} C_{p} N_{t}\left(n(x) p(x)-n_{e}(x) p_{e}(x)\right)}{C_{n}\left(n(x)+n_{e}(x)\right)+C_{p}\left(p(x)+p_{e}(x)\right)}
$$

here $C_{\mathrm{n}}$ and $C_{\mathrm{p}}$ are the capture cross-sections for electrons and holes, $N_{\mathrm{t}}$ is the density of electron traps, and $n_{\mathrm{e}}$ and $p_{\mathrm{e}}$ are the density of free electrons and holes in equilibrium $\left(n_{\mathrm{e}} p_{\mathrm{e}}=n_{\mathrm{i}}{ }^{2}\right)$. Reducing the trap density in the BHJ layer can reduce trap-assisted recombination and hence increase the FF of OSCs, e.g., trap-filling of the polymer donors or acceptors with molecular additives has been demonstrated.[2, 84] 


\subsection{Compositional Morphology in Bulk Heterojunctions}

Commonly, drift-diffusion models consider the OSC in one dimension (1D drift-diffusion). The DA BHJ represented as a homogenous effective medium that transports both electrons and holes sandwiched between the electrodes and therefore characterized by single mobility for each carrier.[10] Different variants of drift-diffusion OSC models have been developed, allowing variation of parameters in one and two dimensions to allow some analysis of the effect of morphology and morphological disorder on OSC performance.[80, 120-124] There are two types of disorder, which can affect OSC device performance in different ways: energetic disorder, which is usually a consequence of the conformational freedom of the molecules or polymer chains, and structural disorder, results from the BHJ phase separation that can lead to "dead-ends" and other morphological conditions that are not optimal for carrier transport.[125] Several studies have examined the effects of energetic disorder on OSC performance, usually assuming a Gaussian distribution of energetic states or an exponential tail of trap states in 1D drift-diffusion simulations.[123, 124]

(a)

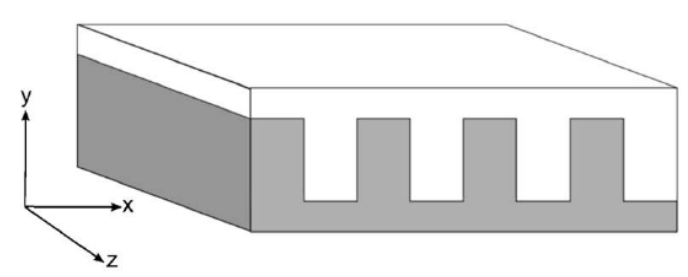

(c)

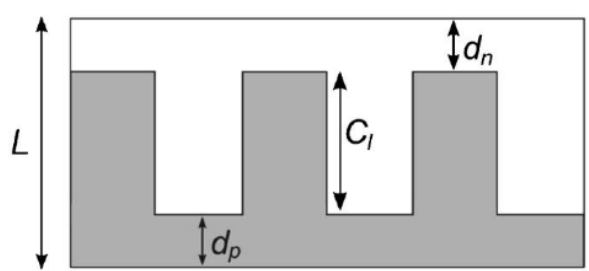

Type I (b)
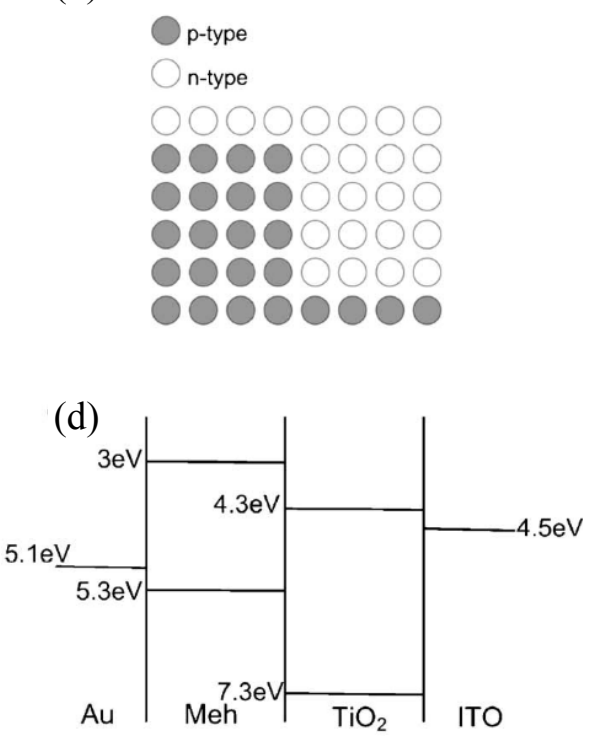
Fig 8.3. (a) Schematic diagram of the devices to be modelled. (b) Their representation on a 2D lattice. (c) Device parameters; $C_{\mathrm{H}}$ is the channel height, $C_{\mathrm{W}}$ he channel width, and $d_{\mathrm{n}}$ and $d_{\mathrm{p}}$ are the blocking layers for electrons and holes, respectively. (d) Energy diagram for an $\mathrm{ITO} / \mathrm{TiO}_{2} / \mathrm{MEH}-\mathrm{PPV} / \mathrm{Au}$ device. Reprinted with permission from Martin et al., J. Appl. Phys., 2007, 102, 104506. Copyright (C 2007, American Institute of Physics.

Other works have studied the effects of phase separation and component distribution on device performance by performing 2D or 3D drift-diffusion simulations.[120, 122, 126-129] In that case, the 1D model can be extended into a more sophisticated simulation with explicit consideration of donor and acceptor phase (D/A model or 2D model) is thus necessary. A 2D or 3D grid utilized to simulate the blend morphology, in which each node represents either the donor, the acceptor phase, or a mixed phase of the two materials. Buxton and Clarke were the first in 2006 who used the drift-diffusion model, which include information about the morphology.[120]

Martin et al.[130] suggested an ideal ordered BHJ for the 2D drift-diffusion simulation. They represented a 2D ordered heterojunction rectangular columns, consisting of purely acceptor and donor materials (Fig 8.3). The key parameters are the height and width of the channels $\left(C_{\mathrm{H}}\right.$ and $C_{\mathrm{W}}$, respectively) and the thickness of the electron and hole blocking layers ( $d_{\mathrm{n}}$ and $d_{\mathrm{p}}$, respectively). From their calculation, the optimal channel height, which is in order of $100 \mathrm{~nm}$ (depending on the recombination strength), appears to be a trade-off between the interface area (which influences exciton dissociation) and average distance the charges must travel. 


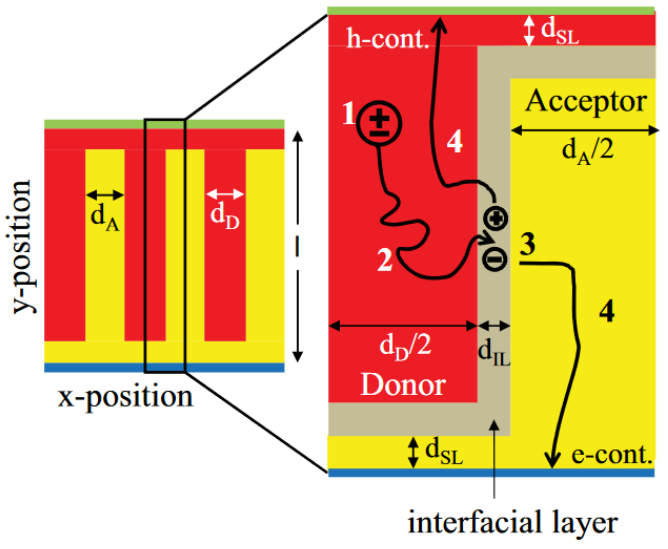

(a) (b)

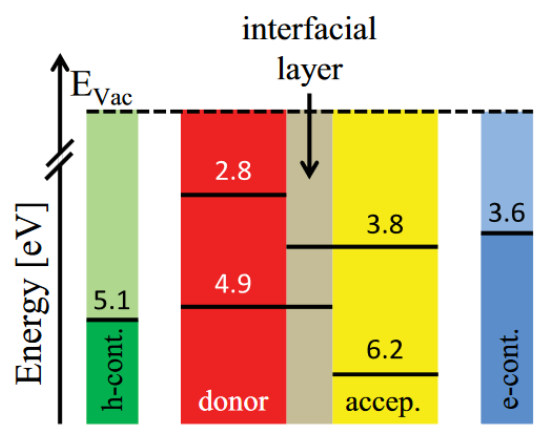

(c)

Fig 8.4. Scheme of the D/A model. (a) Idealistic morphology of an OSC. (b) Symmetry element and schematic visualization of the relevant processes. (1) Excitons are created upon absorption of photons in donor phase. (2) Excitons diffuse and eventually reach the interfacial layer or decay. (3) Excitons dissociate into electrons and holes in the IL. (4) Charge carriers are transported in their respective phase (electrons in acceptor and holes in donor) and are collected at respective contact or recombine in interfacial layer (not shown). (c) Energetic scheme of the respective phases together with the standard values for the simulations. As the electrodes can be in contact with all materials (donor, acceptor, and IL), a white space is drawn between the electrodes and the photoactive region. Reprinted with permission from Stelzl and Würfel, Phys. Rev. B, 2012, 86, 075315. Copyright (C) 2012, American Physical Society.

Stelzl and Würfel [129] used an idealistic morphology of an OSC (Fig 8.4), and both donor and acceptor are modeled as individual semiconducting phases with individual HOMO and LUMO levels. The model includes morphology explicitly and excitonic effects. They also introduced the area where both phases are adjacent to each other, which considered as a thin, finite volume interfacial layer (IL) with HOMO and LUMO levels equal to that of the donor HOMO level and acceptor LUMO level respectively. The IL serves as auxiliary material, in which exciton dissociation and bimolecular recombination of free charge carriers occur. It is important to note that the generation and recombination of electrons and holes are restricted to the IL. The same equations as in the 1D model are solved self-consistently for the 2D model, with the addition of the exciton continuity equation, which cover exciton generation, diffusion, dissociation, and their decay throughout the device. Position-dependent generation profile of donor and acceptor phases can be incorporated but for the reasons of simplicity F. Stelz and U. 
Wurfel only set the exciton generation rate to be nonzero in the donor phase. With the 2D model, they were able to simulate solar cell characteristics versus the diameter of the donor and acceptor phases.[129]

On the other hand, the fabrication of devices with ordered structure via morphology engineering is challenging and requires expensive techniques. Ray and Alam showed that the intrinsic random morphology obtained by inexpensive solution-processing does not necessarily translate into a lower performance compared to ordered heterojunctions.[126] They demonstrated that an optimised disordered BHJ performs almost as well as an ordered heterojunction (in their example, the best PCE values for the disordered and ordered heterojunction were $5.5 \%$ and $6.1 \%$, respectively).

Buxton and Clarke investigated the effect of complex diblock copolymer morphologies by solving the equations for the electrostatic potential and the exciton, hole, and electron density in two dimensions, as explained before.[120] The phase separation in diblock copolymers leads to a bicontinuous network of donor and acceptor domains, which can be oriented through surface-induced ordering or by applying an electric field.[120] In order to predict the morphologies in these diblock copolymers, they employed the Flory-Huggins Cahn-Hillard model. The model treats the phase separation kinetics of DA blend based on the minimization of the total energy and evaluates the change of local composition with anneal time. The FloryHuggins mean-field theory modeled the free energy of mixing.[120] The oriented morphology, which we refer to as columnar, performs much better than the bilayer and disordered devices. In the former, the DA interfacial area, where exciton dissociation occurs, is larger than in the bilayer. Moreover, in the columnar morphology there are no dead-ends that force the charges to move against the built-in electric field for part of their travel towards the electrodes. The larger interfacial area increases the exciton dissociation efficiency, and the absence of deadends in the columnar morphology ensures an easier extraction of charges compared to a disordered morphology. 
(a)
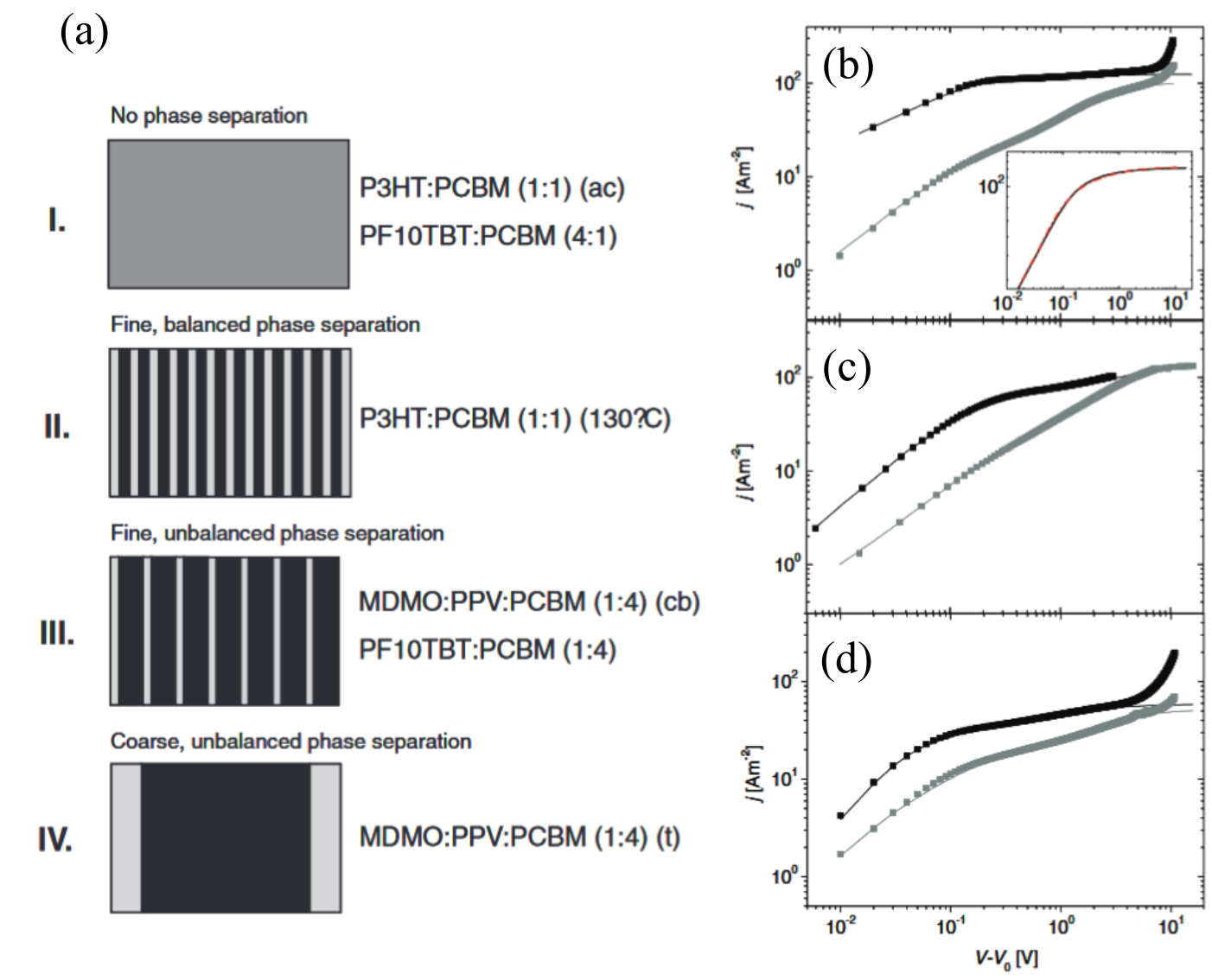

Fig 8.5. (a) Schematic representation of polymer:PCBM blend morphologies as proposed on basis of combined morphology characterizations with transmission electron microscopy (TEM), atomic force microscopy (AFM), and scanning tunneling microscopy (STM). The grey slabs represent the most polymer rich phase and black phase represent the most fullerene rich phase. (b) Measured (symbols) and simulated (lines) current vs. reduced bias $\left|\mathrm{V}-\mathrm{V}_{\mathrm{OC}}\right|$ curves for polymer:PCBM BHJ solar cells. The active layer consist of (a) P3HT(R):PCBM, spin-coated from chlorobenzene, annealed (black), untreated (grey), inset: solid line: 1D calculation, red dash-dotted line: 2D calculation; (c) PF10TBT:PCBM at weight ratio 1:4 (black) and 4:1 (grey); (d) MDMO-PPV:PCBM from chlorobenzene at $1500 \mathrm{rpm}$ (black) and toluene at $800 \mathrm{rpm}$ (grey). The sharp increase in measured current around $10 \mathrm{~V}$ is due to minority carrier injection. Reprinted with permission from Maturova et al., Adv. Funct. Mater., 2011, 21, 261-269. Copyright (C) 2011, Wiley-VCH.

Finck and Schwartz also simulated the effects of DA mixed-composition by utilizing morphologies generated by Cahn-Hilliard $(\mathrm{CH})$ modeling[131] of binary fluid phase separation.[125] With the $\mathrm{CH}$ model, the component domain sizes can be tuned with a single parameter. Then, a mixed interfacial region by smoothing the binary morphology in a continuously controllable fashion can be introduced. The generated morphologies then incorporated into a drift-diffusion simulator with device parameters directly affected by the compositional morphology are the mobilities and generation rate of charge carriers. To 
determine the carrier generation profile to be used in the simulation, first, a transfer-matrix calculation using an effective-medium approximation to calculate the wavelength-dependent absorption profile, which determines where excitons are generated, through the device based on the AM1.5G spectrum.[101] They then set that charge carriers are generated predominantly in proximity to the interface between the two components of Cahn-Hilliard or empirical morphologies. In contrast to the KMC simulation from [132], Finck and Schwartz illustrate that the mixed-composition phase can have both beneficial and detrimental effects on the overall performance of polymer/fullerene BHJ photovoltaic devices.[125]

(a)

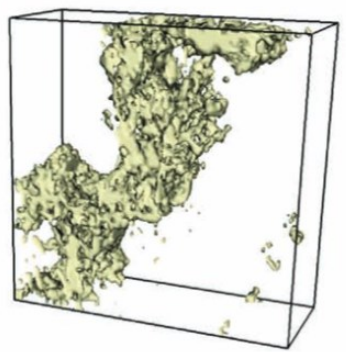

(d)

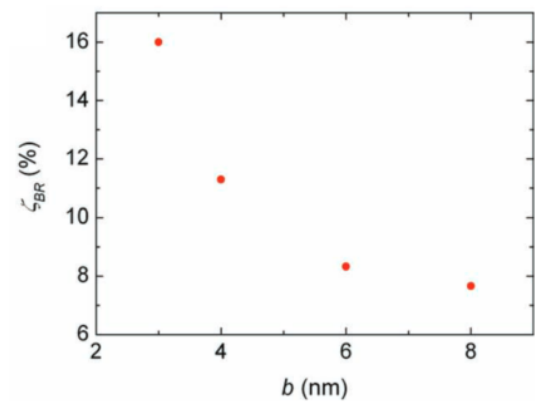

(b)

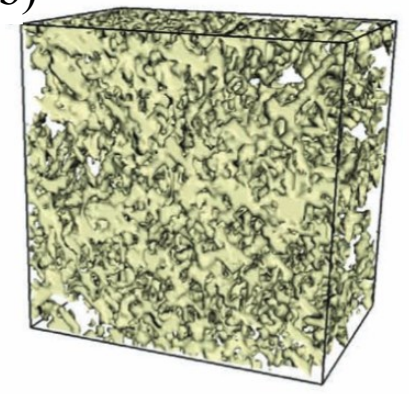

(e)

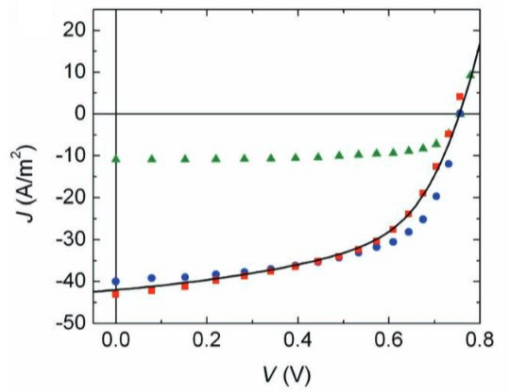

(c)
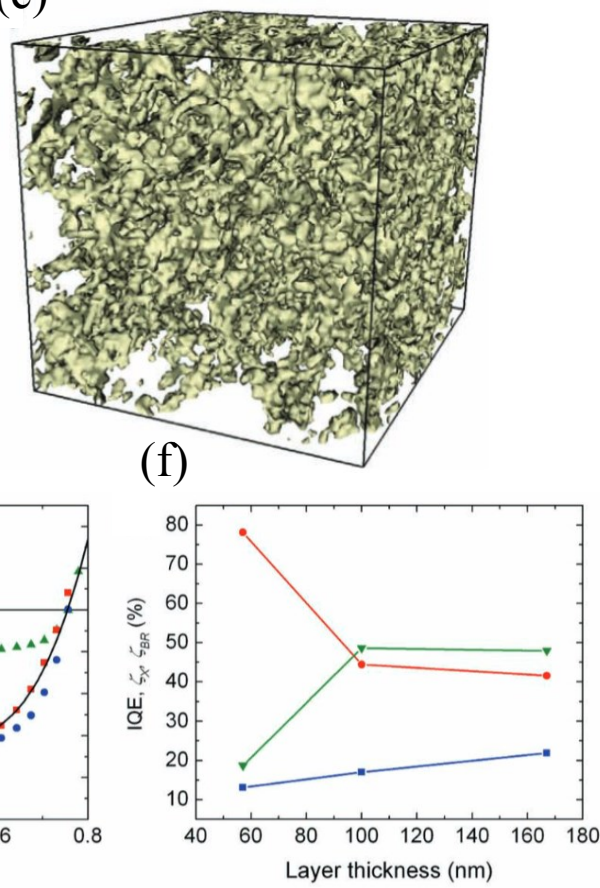

Fig 8.6. Reconstructed volumes of $\mathrm{P} 3 \mathrm{HT} / \mathrm{ZnO}$ layers of (a) $57 \mathrm{~nm}$, (b) $100 \mathrm{~nm}$, and (c) $167 \mathrm{~nm}$ thickness. P3HT appears transparent, $\mathrm{ZnO}$ gray. The lateral dimensions are $140 \times 140 \mathrm{~nm}^{2}$, which is a quarter of the total simulation volume. The front of the image corresponds to the anode. (d) The bimolecular recombination loss calculated with the drift-diffusion model ( $b$ is average feature size). (e) Simulated J$\mathrm{V}$ of the three different thicknesses ((green triangles) $57 \mathrm{~nm}$, (blue dots) $100 \mathrm{~nm}$, (red squares) $167 \mathrm{~nm}$ ). For comparison, the experimental J-V of a $162 \mathrm{~nm}$ thick device is also included (line). (b) Internal quantum efficiency (green triangles), exciton loss $\zeta_{\mathrm{X}}$ (red dots) and bimolecular recombination loss $\zeta_{\mathrm{BR}}$ (blue squares). Lines are intended to guide the eye. Reprinted with permission from Koster et al., Adv. Energy Mater., 2013, 3, 615-621. Copyright (C) 2013, Wiley-VCH.

Several other works of 2D drift-diffusion models, most notably developed by Shah and Ganesan include semi-rigid or rod-like structures and to incorporate anisotropy in exciton and charge transport,[128] DA materials of rod-coil block copolymers represented by a lamellar 
structure. While most of the aforementioned 2D simulation works were not compared to experimental data, Maturova et al.[133, 134] made the first attempt to compare simulations and experimental data by using 2D drift-diffusion model in which alternating slabs of two phases

mimics the complex morphology of a polymer-fullerene blend (Fig 8.5). Furthermore, Koster et al. used a 3D drift-diffusion model to explain the role of morphology in hybrid P3HT/ZnO solar cells with the morphology was imaged with 3D electron microscopy and tomography (Fig 8.6).[127] They showed that the IQE in $\mathrm{P} 3 \mathrm{HT} / \mathrm{ZnO}$ solar cells is a trade-off between charge transport and exciton harvesting. They also analyzed the impact of isolated clusters of acceptor and dead-ends in the morphology on the overall device efficiency. For their particular set of morphologies, efforts to remove isolated clusters of the $\mathrm{ZnO}$ phase will not improve device performance. Although the 2D/3D model requires longer simulation times than in the $1 \mathrm{D}$ case, the implementation of 2D and 3D models can provide insight into the effect of the morphology on the device performance.

\subsection{Modeling of Device Performance of Organic Solar Cells}

Drift-diffusion models have been demonstrated to be effective at fitting experimental OSC J-V data, and in doing so, provide critical insights into underlying physical mechanisms. For example, Koster et al.[115] showed that the FF of the J-V of organic solar cells is sensitive to the bimolecular recombination rate while also found that the rate required to fit the experimental data for P3HT:PCBM devices with the drift-diffusion model is lower than that predicted by Langevin equation (eq.14). The same group also examined the thickness dependence of MDMO-PPV:PCBM OSCs. It showed that the expected increase in photocurrent with thickness was not realized experimentally due to bimolecular recombination increase.[135] Driftdiffusion fitting for all-polymer blend OSCs showed how inefficient geminate recombination, modeled by Onsager-Braun theory, can also lead to poor FF. [136] Similarly, important work 
from Kuik et al.[137] showed that in addition to Langevin type recombination, the trap-assisted recombination rate needs to be included in the model to explain VOC's slope versus the logarithm of the light intensity that is larger than thermal voltage $\mathrm{kT} / \mathrm{q}$.

Drift-diffusion methods can also model changes in active-layer mobility, thickness, or light intensity. Mauer et al.[138] used a 1D numerical drift-diffusion device simulator (SETFOS from FLUXiM AG) to simulate the J-V characteristics of a P3HT:PCBM device measured at various temperatures. They showed that the charge generation in the device is not field or temperature-dependent, and nongeminate recombination is sufficient to describe the photocurrent's bias dependence. Bartelt et al.[109] reproduced the experimental data of P3HT:PCBM solar cells that have been annealed at different temperatures, using charge mobility as the parameter that is changes over temperatures. Their simulation was also able to reproduce the experimentally measured FF versus device thickness and light intensity trends. They found that that space-charge buildup and recombination significantly limit the performance of BHJ devices even when the electron and hole mobility is balanced. Firdaus et al.[7] demonstrated an excellent agreement between the experimental and simulated J-V curves for different material systems and layer thicknesses. They showed that the simulator tool could capture the physical processes that govern charge carrier photogeneration, transport, and recombination in these NFA-based BHJ OSCs.

One should note that the drift-diffusion equations use steady-state mobilities (such as the one obtained from space-charge limited current (SCLC) technique) as an input and do not include any effects of charge carrier dispersion. The relative importance of the dispersive effect on OSC devices' performance was conflicting in the literature.[139-143] Le Corre et al.[142] recently showed that the dispersion of the current plays a limited role in the charge carrier extraction in OSC devices. Feledikis et al.[143], argued the importance of fast and dispersive transport in OSC. Using Monte Carlo simulations, they could accurately reproduce the transient photocurrent response for PTB7:PC $71 \mathrm{BM}$ and TQ1:PC 71 BM OSC devices. Nevertheless, the 
excellent agreement between drift-diffusion simulation and experimental results shows that steady-state mobilities are sufficient to characterize the transport and extraction in OSC devices.

The drift-diffusion models have also been used to reproduce experimentally measured device performance using (photo)physical parameters obtained from transient spectroscopy or charge transport measurements. Karuthedath et al.[12] used bimolecular rate constant, obtained by TA and TDCF measurements, as an input for the simulation. It yields an excellent fits with the experimental J-V data of ternary DR3:ICC6:PC ${ }_{71} \mathrm{BM}$ solar cells. Similarly, they could reasonably reproduce the experimentally measured $\mathrm{J}-\mathrm{V}$ of TQ1:PC ${ }_{71} \mathrm{BM}$ using the bimolecular rate constant inferred from TA and using charge densities at short-circuit and open-circuit conditions.[144] The same group, with the help of drift-diffusion simulation, found that using recombination based on TDCF measurement leads to a larger overestimation of recombination in the low carrier extraction regime (i.e., close to $\mathrm{V}_{\mathrm{OC}}$ ).[144-146] This overestimation is most likely caused by underestimating the charge carrier density in TDCF experiments, as discussed in ref [147]. The simulated $\mathrm{J}-\mathrm{V}$ curves are often in good agreement with the experimentally measured ones, yet the match is not absolute.[144, 145] Karuthedath et al.[144] recently showed that since the carrier concentration in the device typically varies significantly between $V_{\mathrm{OC}}$ and $J_{\mathrm{SC}}$ conditions, a single recombination coefficient value as used in the simulation does not adequately fit the entire bias range. Apart from the recombination rate constant obtained from TA, Firdaus et al.[11] also showed that recombination analyses obtained from the steady-state transport measurement and the analytical model proposed by Wetzelaer et al.[148] yields excellent agreement between the experimental and simulated OSC device performance.

Drift-diffusion simulation was also able to well-reproduce transient signals of OSC devices. For example, Wheeler et al.[149] show that drift-diffusion simulations were in good agreement with the charge extraction (CE) and transient-photovoltage (TPV) measurements. Albrecht et al.[18] have been able to fit the TDCF signal using drift-diffusion simulations. They also see 
that during the first $50 \mathrm{~ns}$ after the charge generation, a small effect of mobility relaxation has to be taken into account in order to reproduce the transient signal.

\subsection{Modeling efficiency limits of OSC}

The OSC modeling, as discussed in the previous section, has demonstrated the ability to capture the physical processes that govern charge carrier photogeneration, transport, and recombination in BHJ OSCs. Therefore, the limit to organic photovoltaic (OSC) cell PCE may seem an exciting discussion in recent years that naturally could be answered by the OSC simulation. The drift-diffusion model has estimated the ultimate efficiency of BHJ solar cells. In 2006 Koster and coworkers calculated the ultimate efficiency of polymer-fullerene BHJ solar cells by using an advanced drift-diffusion device model.[150] As a starting point, they simulated 3.5\% PCE P3HT:PCBM absorber to obtain typical BHJ solar cell device parameters. While P3HT:PCBM solar cells represent efficient photon-to-electron conversion, they are limited by a LUMOLUMO offset that is larger than needed to overcome the charge pair binding energy and by too large an optical gap $\left(E_{\mathrm{g}}=2.1 \mathrm{eV}\right)$. Therefore, using parameters obtained from the simulation of P3HT:PCBM device, they optimized the LUMO-level offset, the layer thickness, and the charge carrier mobility. They found an ultimate PCE of $10.8 \%$ for a $200 \mathrm{~nm}$ thick layer and an optimum band-gap of $1.9 \mathrm{eV}$. In calculating the efficiency limits, the authors assumed a realistic absorption spectrum and did not insist that all photons of $E>E_{\mathrm{g}}$ are absorbed. Furthermore, Koster et al.[151] presented three different theoretical approaches to identify pathways to obtain OSCs with PCE over 20\%. First, with radiation limit model showed that organic solar cells can be as efficient as their organic counterparts if CT state absorption is sufficiently weak. Next, a model based on Marcus electron transfer rates showed the important of reducing reorganization energies and harnessing absorption from both donor and acceptor. Finally, using drift-diffusion model the introduced the effect of increasing the dielectric constant $\varepsilon$ of the absorber material on the PCE of organic solar cells. A larger $\varepsilon$ leads to a smaller exciton binding energy and a 
smaller LUMO-LUMO offset would be sufficient for quantitative free charge carrier generation. Their model suggests that by increasing $\varepsilon$ for $3-8$, the PCE would increase for $\sim 12 \%$ to about $20 \%$. At a dielectric constant of 8 , the exciton binding energy would be in the range of $25 \mathrm{meV}$ which would allow the generation of free charge carriers via thermal dissociation.

(a)

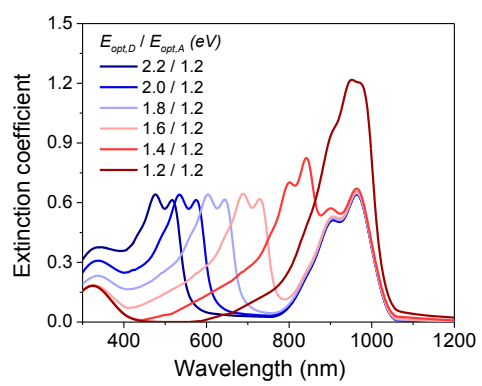

(b)

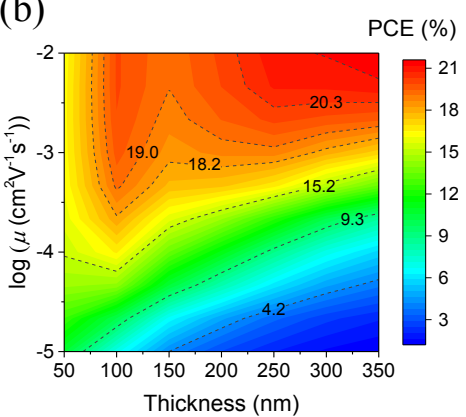

(c)

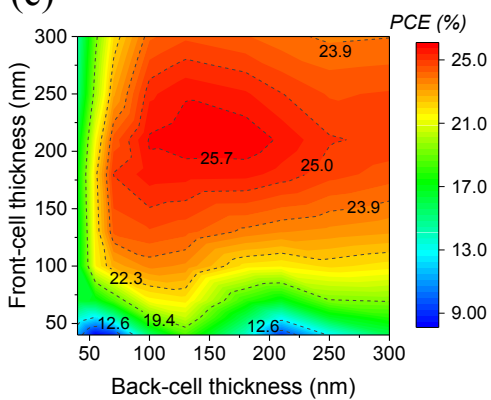

Fig 8.7. (a) Generated extinction coefficient spectra of several BHJ films used for the simulation and obtained by shifting the spectra of donor from $2.2 \mathrm{eV}$ to $1.2 \mathrm{eV}$ and using the spectra of NFA with bandgap of $1.2 \mathrm{eV}$. (b) Efficiency prediction (plotted in color scale, with numbers on the contour lines representing PCE in \%) for single-junction NFA OSCs as a function of charge mobility $\left(\mu=\mu_{\mathrm{h}}=\mu_{\mathrm{e}}\right)$ and active layer thickness. (c) Efficiency prediction of 2-terminal NFA-based tandem OSCs (the optical bandgaps for the front and back-cell were $2 \mathrm{eV}$, and $1.4 \mathrm{eV}$, respectively) simulated from optical and electrical modelling. Reprinted under the terms of the Creative Commons CC BY license (Firdaus et al., Adv. Sci., 2019, 3, 615-621). Copyright 2019, Wiley-VCH.

Wurfel et al.[152] simulated the effect of the charge-carrier mobility and absorber bandgap on the achievable PCE. A variable offset between the LUMO levels of donor and acceptor was used. Efficiencies beyond $25 \%$ are predicted only for zero offset $\left(E_{\mathrm{G}, \text { abs }}\right.$ was about $\left.1.55 \mathrm{eV}\right)$, which is somewhat unlikely to realize with organic DA blends. Nevertheless, efficiencies of $18 \%$ and higher are within reach for a realistic offset of $0.3 \mathrm{eV}$, provided that the mobility is in excess of $10^{-2} \mathrm{~cm}^{2} \mathrm{~V}^{-1} \mathrm{~s}^{-1}$. Note that in their work, Wurfel et al. assumed full absorption of all photons of the AM1.5G spectrum with photon energies larger than the bandgap of donor. Recently, Firdaus et al. include the influence of the absorption of the donor and NFA and employ realistic absorption spectrum (Fig 8.7a).[7] Additionally, they also used a very low energy loss $\left(E_{\mathrm{opt}, \text { lowest }}-E_{\mathrm{CT}}=0.1 \mathrm{eV}\right)$ in their calculation, as often observed experimentally in nonfullerene-based OSC.[61] In their simulation, they treated explicitly the effect of several 
parameters such as active-layer absorption, thicknesses, charge mobilities and recombination rate constant on efficiency limits. They found that with the already reported hole and electron mobilities of $5 \times 10^{-4} \mathrm{~cm}^{2} \mathrm{~V}^{-1} \mathrm{~s}^{-1}$, single-junction NFA-based OSCs can potentially reach PCEs of over $18 \%$ if non-geminate recombination rate constant could be reduced to $1 \times 10^{-12} \mathrm{~cm}^{3} \mathrm{~s}^{-1}$ and IQE increased to $95 \%$. Moreover, PCE values in excess of $20 \%$ (Fig. 8.7b) is shown to be within reach even for single-junction OSCs either by increasing the charge carrier mobility and active layer thickness to $>10^{-3} \mathrm{~cm}^{2} \mathrm{~V}^{-1} \mathrm{~s}^{-1}$ and to $>200 \mathrm{~nm}$, respectively, or by reducing the recombination rate constant $(k)$ to $\leq 1 \times 10^{-13} \mathrm{~cm}^{3} \mathrm{~s}^{-1}$. By combining optical transfer matrix modelling with the drift-diffusion single-cell J-V simulations, they were also able to model 2terminal tandem NFA-based OSC cells. They predicted that engineered tandem cells may achieve PCE values of over $25 \%$ if the electron $\left(\mu_{e}\right)$ and hole $\left(\mu_{h}\right)$ mobilities in the donor and acceptor materials used for the individual sub-cells are balanced $\left(\mu_{e}=\mu_{h}\right)$ and $\geq 10^{-3} \mathrm{~cm}^{2} \mathrm{~V}^{-1} \mathrm{~s}^{-1}$, while $k$ remains low and around $10^{-12} \mathrm{~cm}^{3} \mathrm{~s}^{-1}$ (Fig. 8.7c).

Other several approaches have been used to calculate the efficiency limits of OSC, such as with diode equation, and detailed-balance or Shockley-Quessier (SQ) limit.[153] The detailed balance approach could deliver a rigorous answer to the upper limit PCE of OSC but would require highly ideal materials with properties that are difficult to realize. With this approach, the maximum attainable efficiency of a single-junction conventional solar cell based on a detailed balance formalism mainly reflects the trade-off factors between a high current corresponding to low $E_{\mathrm{g}}$ and a high voltage corresponding to large $E_{\mathrm{g}}$ semiconductors.[154, 155] For BHJ OSC, the voltage loss arising from the difference in the donor and acceptor levels and the existence of a CT state mediating recombination pose limitations. Using the SQ limit approach, Azzouzi et al. recently estimated that the maximum achievable efficiency for BHJ OSC could be over $30 \%$ if the loss only considers radiative recombination (SQ limit). In comparison, it would be approximately $25 \%$ for the nonradiative limit (Fig 8.8).[156] They also estimated a more realistic limit of approximately $20 \%$, considering a limit of $90 \%$ of external 
quantum efficiency (EQE) and $80 \%$ FF. There are also some empirical approaches to gain insight into the improvements that may be achievable in practice. Readers wishing to learn about those different approaches in more detail could refer to these review papers.[157, 158]

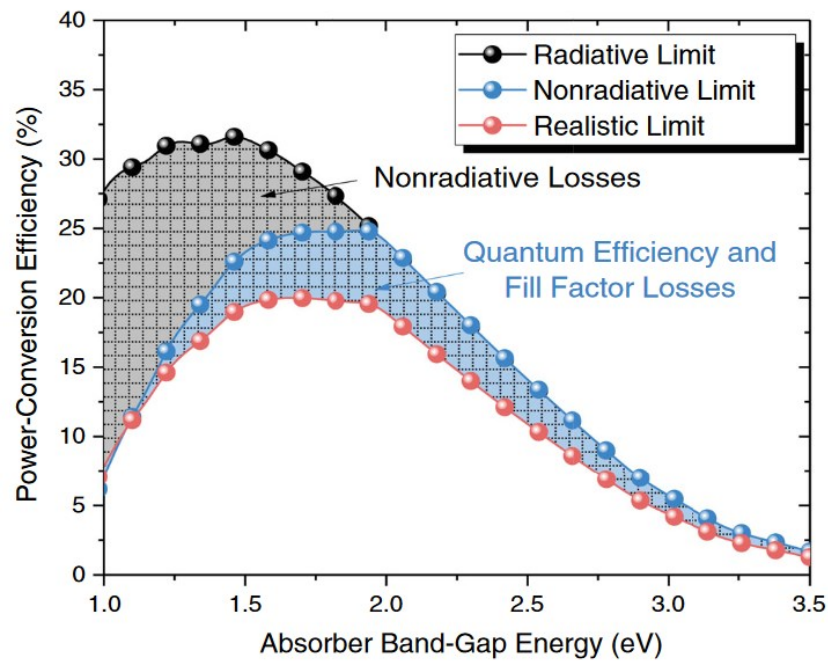

Fig 8.8. Predicted PCE compared with the radiative limit. The black line is the SQ limit using theAM1.5G sun spectrum, where only radiative recombination is considered; the blue line is the nonradiative limit considering a perfect charge collection (100\% of the EQE calculated from modeled absorption spectra) and the ideal Shockley equation (ideality factor of 1); the red line is the more realistic limit assuming $90 \% \mathrm{EQE}$ absorption and $80 \% \mathrm{FF}$. Reprinted under the terms of the Creative Commons Attribution 4.0 International License (Azzouzi et al., Phys. Rev. X, 2018, 8, 031055). Copyright 2018, American Physical Society.

\section{Summary and Outlook}

In summary, we have reviewed the fundamental physical processes relevant to photogeneration of charge carriers, starting from exciton generation to charge collection and the interplay between recombination and collection of photogenerated charge carriers. Drift-diffusion modelling, which further discussed in this chapter, has demonstrated the valuable role that macroscopic modeling can play in the ongoing development of BHJ OSC. The morphology model incorporated into the simulations supports the accepted view that the blend's morphology is crucial to its photophysical properties. Further improvements in the descriptions of the morphology and investigation of the morphology of NFA-based OSC will only improve matters. Compared to fullerene-based OSC, large domain sizes of 20-50 nm often reported for high- 
efficiency NFA-based BHJ cells.[159-162] The exciton diffusion coefficient of NFA, such as IDIC, has also been found to be two orders of magnitude higher than $\mathrm{PC}_{71} \mathrm{BM}$.[163] The implication of a higher diffusion coefficient or diffusion length would be tremendous for OSC. Large, ordered, and pure domains expectedly enhance charge separation and transport, suppress recombination, and improve FFs. Enhancements of exciton diffusion lengths may even eliminate the need for the BHJ morphology. Further improvements in device performance would be mitigating the energy losses that might require conceptually new material designs. Another pragmatic way is to increase the donor and acceptor's absorption coefficient and push the EQE toward unity.

\section{Acknowledgements}

The authors acknowledge financial support from King Abdullah University of Science and Technology (KAUST).

\section{References}

[1] LIN, Y., ADILBEKOVA, B., FIRDAUS, Y., YENGEL, E., FABER, H., SAJJAD, M., ZHENG, X., YARALI, E., SEITKHAN, A., BAKR, O. M., EL-LABBAN, A., SCHWINGENSCHLÖGL, U., TUNG, V., MCCULLOCH, I., LAQUAI, F. \& ANTHOPOULOS, T. D. 2019. 17\% Efficient Organic Solar Cells Based on Liquid Exfoliated WS2 as a Replacement for PEDOT:PSS. Advanced Materials, 31, 1902965.

[2] LIN, Y., FIRDAUS, Y., NUGRAHA, M. I., LIU, F., KARUTHEDATH, S., EMWAS, A.-H., ZHANG, W., SEITKHAN, A., NEOPHYTOU, M., FABER, H., YENGEL, E., MCCULLOCH, I., TSETSERIS, L., LAQUAI, F. \& ANTHOPOULOS, T. D. 2020. $17.1 \%$ Efficient Single-Junction Organic Solar Cells Enabled by n-Type Doping of the Bulk-Heterojunction. Advanced Science, 7, 1903419.

[3] CUI, Y., YAO, H., ZHANG, J., XIAN, K., ZHANG, T., HONG, L., WANG, Y., XU, Y., MA, K., AN, C., HE, C., WEI, Z., GAO, F. \& HOU, J. Single-Junction Organic Photovoltaic Cells with Approaching 18\% Efficiency. Advanced Materials, 1908205.

[4] LIU, Q., JIANG, Y., JIN, K., QIN, J., XU, J., LI, W., XIONG, J., LIU, J., XIAO, Z., SUN, K., YANG, S., ZHANG, X. \& DING, L. 2020. 18\% Efficiency organic solar cells. Science Bulletin, 65, 272.

[5] LIU, L., KAN, Y., GAO, K., WANG, J., ZHAO, M., CHEN, H., ZHAO, C., JIU, T., JEN, A.-K.-Y. \& LI, Y. 2020. Graphdiyne Derivative as Multifunctional Solid Additive in Binary Organic Solar Cells with $17.3 \%$ Efficiency and High Reproductivity. Advanced Materials, 32, 1907604. 
[6] MENG, L., ZHANG, Y., WAN, X., LI, C., ZHANG, X., WANG, Y., KE, X., XIAO, Z., DING, L., XIA, R., YIP, H.-L., CAO, Y. \& CHEN, Y. 2018. Organic and solutionprocessed tandem solar cells with 17.3\% efficiency. Science, 361, 1094-1098.

[7] FIRDAUS, Y., LE CORRE, V. M., KHAN, J. I., KAN, Z., LAQUAI, F., BEAUJUGE, P. M. \& ANTHOPOUlOS, T. D. 2019. Key Parameters Requirements for NonFullerene-Based Organic Solar Cells with Power Conversion Efficiency $>20 \%$. Advanced Science, 6, 1802028.

[8] BRÉDAS, J.-L., NORTON, J. E., CORNIL, J. \& COROPCEANU, V. 2009. Molecular Understanding of Organic Solar Cells: The Challenges. Accounts of Chemical Research, 42, 1691-1699.

[9] VOTER, A. F. INTRODUCTION TO THE KINETIC MONTE CARLO METHOD. 2007 Dordrecht. Springer Netherlands, 1-23.

[10] KOSTER, L. J. A., SMITS, E. C. P., MIHAILETCHI, V. D. \& BLOM, P. W. M. 2005. Device model for the operation of polymer/fullerene bulk heterojunction solar cells. Physical Review B, 72, 085205.

[11] FIRDAUS, Y., HE, Q., LIN, Y., NUGROHO, F. A. A., LE CORRE, V. M., YENGEL, E., BALAWI, A. H., SEITKHAN, A., LAQUAI, F., LANGHAMMER, C., LIU, F., HEENEY, M. \& ANTHOPOULOS, T. D. 2020. Novel wide-bandgap non-fullerene acceptors for efficient tandem organic solar cells. Journal of Materials Chemistry A, 8, 1164-1175.

[12] KARUTHEDATH, S., FIRDAUS, Y., LIANG, R.-Z., GORENFLOT, J., BEAUJUGE, P. M., ANTHOPOULOS, T. D. \& LAQUAI, F. 2019. Impact of Fullerene on the Photophysics of Ternary Small Molecule Organic Solar Cells. Advanced Energy Materials, 9, 1901443.

[13] KHAN, J. I., ASHRAF, R. S., ALAMOUDI, M. A., NABI, M. N., MOHAMMED, H. N., WADSWORTH, A., FIRDAUS, Y., ZHANG, W., ANTHOPOULOS, T. D., MCCULLOCH, I. \& LAQUAI, F. 2019. P3HT Molecular Weight Determines the Performance of P3HT:O-IDTBR Solar Cells. Solar RRL, 3, 1900023.

[14] NEUKOM, M., ZUFLE, S., JENATSCH, S. \& RUHSTALLER, B. 2018. Optoelectronic characterization of third-generation solar cells. Science and Technology of Advanced Materials, 19, 291-316.

[15] DAHLSTRÖM, S., SANDBERG, O. J., NYMAN, M. \& ÖSTERBACKA, R. 2018. Determination of Charge-Carrier Mobility and Built-In Potential in Thin-Film Organic M-I-M Diodes from Extraction-Current Transients. Physical Review Applied, 10, 054019.

[16] MCNEILL, C. R., HWANG, I. \& GREENHAM, N. C. 2009. Photocurrent transients in all-polymer solar cells: Trapping and detrapping effects. Journal of Applied Physics, 106, 024507.

[17] SANDBERG, O. J. \& NYMAN, M. 2019. Charge extraction by a linearly increasing voltage of photo-generated carriers: The influence of two mobile carrier types, bimolecular recombination, and series resistance. Organic Electronics, 64, 97-103.

[18] ALBRECHT, S., SCHINDLER, W., KURPIERS, J., KNIEPERT, J., BLAKESLEY, J. C., DUMSCH, I., ALLARD, S., FOSTIROPOULOS, K., SCHERF, U. \& NEHER, D. 2012. On the Field Dependence of Free Charge Carrier Generation and Recombination in Blends of PCPDTBT/PC70BM: Influence of Solvent Additives. The Journal of Physical Chemistry Letters, 3, 640-645.

[19] ALAMOUDI, M. A., KHAN, J. I., FIRDAUS, Y., WANG, K., ANDRIENKO, D., BEAUJUGE, P. M. \& LAQUAI, F. 2018. Impact of Nonfullerene Acceptor Core Structure on the Photophysics and Efficiency of Polymer Solar Cells. ACS Energy Letters, 3, 802-811. 
[20] CLARKE, T. M. \& DURRANT, J. R. 2010. Charge Photogeneration in Organic Solar Cells. Chemical Reviews, 110, 6736-6767.

[21] BURKE, T. M., SWEETNAM, S., VANDEWAL, K. \& MCGEHEE, M. D. 2015. Beyond Langevin Recombination: How Equilibrium Between Free Carriers and Charge Transfer States Determines the Open-Circuit Voltage of Organic Solar Cells. Advanced Energy Materials, 5, 1500123.

[22] YU, G., GAO, J., HUMMELEN, J. C., WUDL, F. \& HEEGER, A. J. 1995. Polymer Photovoltaic Cells: Enhanced Efficiencies via a Network of Internal Donor-Acceptor Heterojunctions. Science, 270, 1789-1791.

[23] MIKHNENKO, O. V., BLOM, P. W. M. \& NGUYEN, T.-Q. 2015. Exciton diffusion in organic semiconductors. Energy \& Environmental Science, 8, 1867-1888.

[24] DEXTER, D. L. 1953. A Theory of Sensitized Luminescence in Solids. The Journal of Chemical Physics, 21, 836-850.

[25] DEXTER, D. L., KNOX, R. S. \& FÖRSTER, T. 1969. The Radiationless Transfer of Energy of Electronic Excitation between Impurity Molecules in Crystals. physica status solidi (b), 34, K159-K162.

[26] FORSTER, T. 1948. *Zwischenmolekulare Energiewanderung Und Fluoreszenz. Annalen Der Physik, 2, 55-75.

[27] SCHOLES, G. D. 2003. Long-Range Resonance Energy Transfer in Molecular Systems. Annual Review of Physical Chemistry, 54, 57-87.

[28] LUNT, R. R., GIEBINK, N. C., BELAK, A. A., BENZIGER, J. B. \& FORREST, S. R. 2009. Exciton diffusion lengths of organic semiconductor thin films measured by spectrally resolved photoluminescence quenching. Journal of Applied Physics, 105, 053711.

[29] MARCINIAK, H., LI, X.-Q., WÜRTHNER, F. \& LOCHBRUNNER, S. 2011. OneDimensional Exciton Diffusion in Perylene Bisimide Aggregates. The Journal of Physical Chemistry A, 115, 648-654.

[30] TAMAI, Y., OHKITA, H., BENTEN, H. \& ITO, S. 2015. Exciton Diffusion in Conjugated Polymers: From Fundamental Understanding to Improvement in Photovoltaic Conversion Efficiency. The Journal of Physical Chemistry Letters, 6, 3417-3428.

[31] MIKHNENKO, O. V., CORDELLA, F., SIEVAL, A. B., HUMMELEN, J. C., BLOM, P. W. M. \& LOI, M. A. 2008. Temperature Dependence of Exciton Diffusion in Conjugated Polymers. The Journal of Physical Chemistry B, 112, 11601-11604.

[32] DIMITROV, S. D., SCHROEDER, B. C., NIELSEN, C. B., BRONSTEIN, H., FEI, Z. P., MCCUllOCH, I., HEENEY, M. \& DURRANT, J. R. 2016. Singlet Exciton Lifetimes in Conjugated Polymer Films for Organic Solar Cells. Polymers, 8.

[33] YOST, S. R., HONTZ, E., YEGANEH, S. \& VAN VOORHIS, T. 2012. Triplet vs Singlet Energy Transfer in Organic Semiconductors: The Tortoise and the Hare. The Journal of Physical Chemistry C, 116, 17369-17377.

[34] MENKE, S. M., LUHMAN, W. A. \& HOLMES, R. J. 2013. Tailored exciton diffusion in organic photovoltaic cells for enhanced power conversion efficiency. Nature Materials, 12, 152-157.

[35] LUNT, R. R., BENZIGER, J. B. \& FORREST, S. R. 2010. Relationship between Crystalline Order and Exciton Diffusion Length in Molecular Organic Semiconductors. Advanced Materials, 22, 1233-1236.

[36] LIN, J. D. A., MIKHNENKO, O. V., CHEN, J., MASRI, Z., RUSECKAS, A., MIKHAILOVSKY, A., RAAB, R. P., LIU, J., BLOM, P. W. M., LOI, M. A., GARCÍACERVERA, C. J., SAMUEL, I. D. W. \& NGUYEN, T.-Q. 2014. Systematic study of exciton diffusion length in organic semiconductors by six experimental methods. Materials Horizons, 1, 280-285. 
[37] RAISYS, S., KAZLAUSKAS, K., DASKEVICIENE, M., MALINAUSKAS, T., GETAUTIS, V. \& JURSENAS, S. 2014. Exciton diffusion enhancement in triphenylamines via incorporation of phenylethenyl sidearms. Journal of Materials Chemistry C, 2, 4792-4798.

[38] RIM, S.-B., FINK, R. F., SCHÖNEBOOM, J. C., ERK, P. \& PEUMANS, P. 2007. Effect of molecular packing on the exciton diffusion length in organic solar cells. Applied Physics Letters, 91, 173504.

[39] SIM, M., SHIN, J., SHIM, C., KIM, M., JO, S. B., KIM, J.-H. \& CHO, K. 2014. Dependence of Exciton Diffusion Length on Crystalline Order in Conjugated Polymers. The Journal of Physical Chemistry C, 118, 760-766.

[40] WEI, G., LUNT, R. R., SUN, K., WANG, S., THOMPSON, M. E. \& FORREST, S. R. 2010. Efficient, Ordered Bulk Heterojunction Nanocrystalline Solar Cells by Annealing of Ultrathin Squaraine Thin Films. Nano Letters, 10, 3555-3559.

[41] ZHANG, Y., SAJJAD, M. T., BLASZCZYK, O., PARNELL, A. J., RUSECKAS, A., SERRANO, L. A., COOKE, G. \& SAMUEL, I. D. W. 2019. Large Crystalline Domains and an Enhanced Exciton Diffusion Length Enable Efficient Organic Solar Cells. Chemistry of Materials, 31, 6548-6557.

[42] SAJJAD, M. T., ZHANG, Y., GERAGHTY, P. B., MITCHELL, V. D., RUSECKAS, A., BLASZCZYK, O., JONES, D. J. \& SAMUEL, I. D. W. 2019. Tailoring exciton diffusion and domain size in photovoltaic small molecules by annealing. Journal of Materials Chemistry C, 7, 7922-7928.

[43] JIN, X.-H., PRICE, M. B., FINNEGAN, J. R., BOOTT, C. E., RICHTER, J. M., RAO, A., MENKE, S. M., FRIEND, R. H., WHITTELL, G. R. \& MANNERS, I. 2018. Longrange exciton transport in conjugated polymer nanofibers prepared by seeded growth. Science, 360, 897-900.

[44] GREGG, B. A., SPRAGUE, J. \& PETERSON, M. W. 1997. Long-Range Singlet Energy Transfer in Perylene Bis(phenethylimide) Films. The Journal of Physical Chemistry B, 101, 5362-5369.

[45] HERTEL, D. \& BÄSSLER, H. 2008. Photoconduction in Amorphous Organic Solids. ChemPhysChem, 9, 666-688.

[46] DEIBEL, C., MACK, D., GORENFLOT, J., SCHÖLL, A., KRAUSE, S., REINERT, F., RAUH, D. \& DYAKONOV, V. 2010. Energetics of excited states in the conjugated polymer poly(3-hexylthiophene). Physical Review B, 81, 085202.

[47] BAKUliN, A. A., RAO, A., PAVELYEV, V. G., VAN LOOSDRECHT, P. H. M., PSHENICHNIKOV, M. S., NIEDZIALEK, D., CORNIL, J., BELJONNE, D. \& FRIEND, R. H. 2012. The Role of Driving Energy and Delocalized States for Charge Separation in Organic Semiconductors. Science, 335, 1340-1344.

[48] FEW, S., FROST, J. M. \& NELSON, J. 2015. Models of charge pair generation in organic solar cells. Physical Chemistry Chemical Physics, 17, 2311-2325.

[49] ONSAGER, L. 1938. Initial Recombination of Ions. Physical Review, 54, 554-557.

[50] BRAUN, C. L. 1984. Electric field assisted dissociation of charge transfer states as a mechanism of photocarrier production. The Journal of Chemical Physics, 80, 41574161.

[51] MARSH, R. A., HODGKISS, J. M. \& FRIEND, R. H. 2010. Direct Measurement of Electric Field-Assisted Charge Separation in Polymer:Fullerene Photovoltaic Diodes. Advanced Materials, 22, 3672-3676.

[52] VELDMAN, D., İPEK, Ö., MESKERS, S. C. J., SWEELSSEN, J., KOETSE, M. M., VEENSTRA, S. C., KROON, J. M., VAN BAVEL, S. S., LOOS, J. \& JANSSEN, R. A. J. 2008. Compositional and Electric Field Dependence of the Dissociation of Charge Transfer Excitons in Alternating Polyfluorene Copolymer/Fullerene Blends. Journal of the American Chemical Society, 130, 7721-7735. 
[53] GUO, J., OHKITA, H., BENTEN, H. \& ITO, S. 2010. Charge Generation and Recombination Dynamics in Poly(3-hexylthiophene)/Fullerene Blend Films with Different Regioregularities and Morphologies. Journal of the American Chemical Society, 132, 6154-6164.

[54] JAMIESON, F. C., AGOSTINELli, T., AZIMI, H., NELSON, J. \& DURRANT, J. R. 2010. Field-Independent Charge Photogeneration in PCPDTBT/PC70BM Solar Cells. The Journal of Physical Chemistry Letters, 1, 3306-3310.

[55] HOWARD, I. A., MAUER, R., MEISTER, M. \& LAQUAI, F. 2010. Effect of Morphology on Ultrafast Free Carrier Generation in Polythiophene:Fullerene Organic Solar Cells. Journal of the American Chemical Society, 132, 14866-14876.

[56] STREET, R. A., COWAN, S. \& HEEGER, A. J. 2010. Experimental test for geminate recombination applied to organic solar cells. Physical Review B, 82, 121301.

[57] ETZOLD, F., HOWARD, I. A., MAUER, R., MEISTER, M., KIM, T.-D., LEE, K.-S., BAEK, N. S. \& LAQUAI, F. 2011. Ultrafast Exciton Dissociation Followed by Nongeminate Charge Recombination in PCDTBT:PCBM Photovoltaic Blends. Journal of the American Chemical Society, 133, 9469-9479.

[58] OHKITA, H., COOK, S., ASTUTI, Y., DUFFY, W., TIERNEY, S., ZHANG, W., HEENEY, M., MCCULLOCH, I., NELSON, J., BRADLEY, D. D. C. \& DURRANT, J. R. 2008. Charge Carrier Formation in Polythiophene/Fullerene Blend Films Studied by Transient Absorption Spectroscopy. Journal of the American Chemical Society, 130, 3030-3042.

[59] FAIST, M. A., KIRCHARTZ, T., GONG, W., ASHRAF, R. S., MCCULLOCH, I., DE MELLO, J. C., EKINS-DAUKES, N. J., BRADLEY, D. D. C. \& NELSON, J. 2012. Competition between the Charge Transfer State and the Singlet States of Donor or Acceptor Limiting the Efficiency in Polymer:Fullerene Solar Cells. Journal of the American Chemical Society, 134, 685-692.

[60] LI, W., HENDRIKS, K. H., FURLAN, A., WIENK, M. M. \& JANSSEN, R. A. J. 2015. High Quantum Efficiencies in Polymer Solar Cells at Energy Losses below $0.6 \mathrm{eV}$. Journal of the American Chemical Society, 137, 2231-2234.

[61] LIU, J., CHEN, S., QIAN, D., GAUTAM, B., YANG, G., ZHAO, J., BERGQVIST, J., ZHANG, F., MA, W., ADE, H., INGANÄS, O., GUNDOGDU, K., GAO, F. \& YAN, H. 2016. Fast charge separation in a non-fullerene organic solar cell with a small driving force. Nature Energy, 1, 16089.

[62] CHEN, S., LIU, Y., ZHANG, L., CHOW, P. C. Y., WANG, Z., ZHANG, G., MA, W. \& YAN, H. 2017. A Wide-Bandgap Donor Polymer for Highly Efficient Non-fullerene Organic Solar Cells with a Small Voltage Loss. Journal of the American Chemical Society, 139, 6298-6301.

[63] CHEN, S., WANG, Y., ZHANG, L., ZHAO, J., CHEN, Y., ZHU, D., YAO, H., ZHANG, G., MA, W., FRIEND, R. H., CHOW, P. C. Y., GAO, F. \& YAN, H. 2018. Efficient Nonfullerene Organic Solar Cells with Small Driving Forces for Both Hole and Electron Transfer. Advanced Materials, 30, 1804215.

[64] WAN, X., LI, C., ZHANG, M. \& CHEN, Y. 2020. Acceptor-donor-acceptor type molecules for high performance organic photovoltaics - chemistry and mechanism. Chemical Society Reviews, 49, 2828-2842.

[65] PERDIGÓN-TORO, L., ZHANG, H., MARKINA, A., YUAN, J., HOSSEINI, S. M., WOLFF, C. M., ZUO, G., STOLTERFOHT, M., ZOU, Y., GAO, F., ANDRIENKO, D., SHOAEE, S. \& NEHER, D. 2020. Barrierless Free Charge Generation in the HighPerformance PM6:Y6 Bulk Heterojunction Non-Fullerene Solar Cell. Advanced Materials, 32, 1906763. 
[66] YAO, H., QIAN, D., ZHANG, H., QIN, Y., XU, B., CUI, Y., YU, R., GAO, F. \& HOU, J. 2018. Critical Role of Molecular Electrostatic Potential on Charge Generation in Organic Solar Cells. Chinese Journal of Chemistry, 36, 491-494.

[67] YANG, C., ZHANG, J., LIANG, N., YAO, H., WEI, Z., HE, C., YUAN, X. \& HOU, J. 2019. Effects of energy-level offset between a donor and acceptor on the photovoltaic performance of non-fullerene organic solar cells. Journal of Materials Chemistry A, 7, 18889-18897.

[68] JIN, F., YUAN, J., GUO, W., XU, Y., ZHANG, Y., SHENG, C., MA, W. \& ZHAO, H. 2018. Improved Charge Generation via Ultrafast Effective Hole-Transfer in AllPolymer Photovoltaic Blends with Large Highest Occupied Molecular Orbital (HOMO) Energy Offset and Proper Crystal Orientation. Advanced Functional Materials, 28, 1801611.

[69] APLAN, M. P., MUNRO, J. M., LEE, Y., BRIGEMAN, A. N., GRIECO, C., WANG, Q., GIEBINK, N. C., DABO, I., ASBURY, J. B. \& GOMEZ, E. D. 2018. Revealing the Importance of Energetic and Entropic Contributions to the Driving Force for Charge Photogeneration. ACS Applied Materials \& Interfaces, 10, 39933-39941.

[70] BARTESAGHI, D., PÉREZ, I. D. C., KNIEPERT, J., ROLAND, S., TURBIEZ, M., NEHER, D. \& KOSTER, L. J. A. 2015. Competition between recombination and extraction of free charges determines the fill factor of organic solar cells. Nature Communications, 6, 7083.

[71] COROPCEANU, V., CORNIL, J., DA SILVA FILHO, D. A., OLIVIER, Y., SILBEY, R. \& BRÉDAS, J.-L. 2007. Charge Transport in Organic Semiconductors. Chemical Reviews, 107, 926-952.

[72] NICOLAI, H. T., KUIK, M., WETZELAER, G. A. H., DE BOER, B., CAMPBELL, C., RISKO, C., BRÉDAS, J. L. \& BLOM, P. W. M. 2012. Unification of trap-limited electron transport in semiconducting polymers. Nature Materials, 11, 882-887.

[73] KOTADIYA, N. B., MONDAL, A., BLOM, P. W. M., ANDRIENKO, D. \& WETZELAER, G.-J. A. H. 2019. A window to trap-free charge transport in organic semiconducting thin films. Nature Materials, 18, 1182-1186.

[74] FIRDAUS, Y., MAFFEI, L. P., CRUCIANI, F., MÜLLER, M. A., LIU, S., LOPATIN, S., WEHBE, N., NDJAWA, G. O. N., AMASSIAN, A., LAQUAI, F. \& BEAUJUGE, P. M. 2017. Polymer Main-Chain Substitution Effects on the Efficiency of Nonfullerene BHJ Solar Cells. Advanced Energy Materials, 7, 1700834.

[75] GUO, B., LI, W., GUO, X., MENG, X., MA, W., ZHANG, M. \& LI, Y. 2017. High Efficiency Nonfullerene Polymer Solar Cells with Thick Active Layer and Large Area. Advanced Materials, 29, 1702291.

[76] YUAN, J., ZHANG, Y., ZHOU, L., ZHANG, G., YIP, H.-L., LAU, T.-K., LU, X., ZHU, C., PENG, H., JOHNSON, P. A., LECLERC, M., CAO, Y., ULANSKI, J., LI, Y. \& ZOU, Y. 2019. Single-Junction Organic Solar Cell with over 15\% Efficiency Using Fused-Ring Acceptor with Electron-Deficient Core. Joule, 3, 1140-1151.

[77] LIU, G., JIA, J., ZHANG, K., JIA, X. E., YIN, Q., ZHONG, W., LI, L., HUANG, F. \& CAO, Y. 2019. 15\% Efficiency Tandem Organic Solar Cell Based on a Novel Highly Efficient Wide-Bandgap Nonfullerene Acceptor with Low Energy Loss. Advanced Energy Materials, 9, 1803657.

[78] COFFEY, D. C., REID, O. G., RODOVSKY, D. B., BARTHOLOMEW, G. P. \& GINGER, D. S. 2007. Mapping Local Photocurrents in Polymer/Fullerene Solar Cells with Photoconductive Atomic Force Microscopy. Nano Letters, 7, 738-744.

[79] FROST, J. M., CHEYNIS, F., TULADHAR, S. M. \& NELSON, J. 2006. Influence of Polymer-Blend Morphology on Charge Transport and Photocurrent Generation in Donor-Acceptor Polymer Blends. Nano Letters, 6, 1674-1681. 
[80] GROVES, C., KOSTER, L. J. A. \& GREENHAM, N. C. 2009. The effect of morphology upon mobility: Implications for bulk heterojunction solar cells with nonuniform blend morphology. Journal of Applied Physics, 105, 094510.

[81] KOSTER, L. J. A. 2010. Charge carrier mobility in disordered organic blends for photovoltaics. Physical Review B, 81, 205318.

[82] HEIBER, M. C., KISTER, K., BAUMANN, A., DYAKONOV, V., DEIBEL, C. \& NGUYEN, T.-Q. 2017. Impact of Tortuosity on Charge-Carrier Transport in Organic Bulk Heterojunction Blends. Physical Review Applied, 8, 054043.

[83] PROCTOR, C. M., KUIK, M. \& NGUYEN, T.-Q. 2013. Charge carrier recombination in organic solar cells. Progress in Polymer Science, 38, 1941-1960.

[84] YAN, H., MANION, J. G., YUAN, M., GARCÍA DE ARQUER, F. P., MCKEOWN, G. R., BEAUPRÉ, S., LECLERC, M., SARGENT, E. H. \& SEFEROS, D. S. 2016. Increasing Polymer Solar Cell Fill Factor by Trap-Filling with F4-TCNQ at Parts Per Thousand Concentration. Advanced Materials, 28, 6491-6496.

[85] COWAN, S. R., BANERJI, N., LEONG, W. L. \& HEEGER, A. J. 2012. Charge Formation, Recombination, and Sweep-Out Dynamics in Organic Solar Cells. Advanced Functional Materials, 22, 1116-1128.

[86] LANGEVIN, M. P. 1945. *Sur La Recombinaison Des Ions. Journal De Physique Et Le Radium, 6, 1-5.

[87] DEIBEL, C., BAUMANN, A. \& DYAKONOV, V. 2008. Polaron recombination in pristine and annealed bulk heterojunction solar cells. Applied Physics Letters, 93, 163303.

[88] SHUTTLE, C. G., O’REGAN, B., BALLANTYNE, A. M., NELSON, J., BRADLEY, D. D. C., MELLO, J. D. \& DURRANT, J. R. 2008. Experimental determination of the rate law for charge carrier decay in a polythiophene: Fullerene solar cell. Applied Physics Letters, 92, 093311.

[89] JUŠKA, G., GENEVIČIUS, K., NEKRAŠAS, N., SLIAUŽYS, G. \& DENNLER, G. 2008. Trimolecular recombination in polythiophene: fullerene bulk heterojunction solar cells. Applied Physics Letters, 93, 143303.

[90] TANASE, C., BLOM, P. W. M. \& DE LEEUW, D. M. 2004. Origin of the enhanced space-charge-limited current in poly(\$p\$-phenylene vinylene). Physical Review B, 70, 193202.

[91] CRACIUN, N. I., BRONDIJK, J. J. \& BLOM, P. W. M. 2008. Diffusion-enhanced hole transport in thin polymer light-emitting diodes. Physical Review B, 77, 035206.

[92] KIRCHARTZ, T. \& NELSON, J. 2012. Meaning of reaction orders in polymer:fullerene solar cells. Physical Review B, 86, 165201.

[93] NELSON, J. 2003. Diffusion-limited recombination in polymer-fullerene blends and its influence on photocurrent collection. Physical Review B, 67, 155209.

[94] DELEDALlE, F., KIRCHARTZ, T., VEZIE, M. S., CAMPOY-QUILES, M., SHAKYA TULADHAR, P., NELSON, J. \& DURRANT, J. R. 2015. Understanding the Effect of Unintentional Doping on Transport Optimization and Analysis in Efficient Organic Bulk-Heterojunction Solar Cells. Physical Review X, 5, 011032.

[95] BENDUHN, J., TVINGSTEDT, K., PIERSIMONI, F., ULLBRICH, S., FAN, Y., TROPIANO, M., MCGARRY, K. A., ZEIKA, O., RIEDE, M. K., DOUGLAS, C. J., BARLOW, S., MARDER, S. R., NEHER, D., SPOLTORE, D. \& VANDEWAL, K. 2017. Intrinsic non-radiative voltage losses in fullerene-based organic solar cells. Nature Energy, 2, 17053.

[96] GURNEY, R. S., LIDZEY, D. G. \& WANG, T. 2019. A review of non-fullerene polymer solar cells: from device physics to morphology control. Reports on Progress in Physics, 82, 036601. 
[97] RAN, N. A., ROLAND, S., LOVE, J. A., SAVIKHIN, V., TAKACS, C. J., FU, Y.-T., LI, H., COROPCEANU, V., LIU, X., BRÉDAS, J.-L., BAZAN, G. C., TONEY, M. F., NEHER, D. \& NGUYEN, T.-Q. 2017. Impact of interfacial molecular orientation on radiative recombination and charge generation efficiency. Nature Communications, 8 , 79.

[98] CRONE, B. K., DAVIDS, P. S., CAMPBELL, I. H. \& SMITH, D. L. 2000. Device model investigation of bilayer organic light emitting diodes. Journal of Applied Physics, 87, 1974-1982.

[99] BRONDIJK, J. J., TORRICELLI, F., SMITS, E. C. P., BLOM, P. W. M. \& DE LEEUW, D. M. 2012. Gate-bias assisted charge injection in organic field-effect transistors. Organic Electronics, 13, 1526-1531.

[100] BARKER, J. A., RAMSDALE, C. M. \& GREENHAM, N. C. 2003. Modeling the current-voltage characteristics of bilayer polymer photovoltaic devices. Physical Review B, 67, 075205.

[101] PETTERSSON, L. A. A., ROMAN, L. S. \& INGANÄS, O. 1999. Modeling photocurrent action spectra of photovoltaic devices based on organic thin films. Journal of Applied Physics, 86, 487-496.

[102] NEUKOM, M. T., REINKE, N. A. \& RUHSTALLER, B. 2011. Charge extraction with linearly increasing voltage: A numerical model for parameter extraction. Solar Energy, $85,1250-1256$.

[103] GUMMEL, H. K. 1964. A self-consistent iterative scheme for one-dimensional steady state transistor calculations. IEEE Transactions on Electron Devices, 11, 455-465.

[104] SCHARFETTER, D. L. \& GUMMEL, H. K. 1969. Large-Signal Analysis of a Silicon Read Diode Oscillator. Ieee Transactions on Electron Devices, Ed16, 64-77.

[105] MENKE, S. M. \& HOLMES, R. J. 2014. Exciton diffusion in organic photovoltaic cells. Energy \& Environmental Science, 7, 499-512.

[106] ZHONG, C., CHOI, H., KIM, J. Y., WOO, H. Y., NGUYEN, T. L., HUANG, F., CAO, Y. \& HEEGER, A. J. 2015. Ultrafast Charge Transfer in Operating Bulk Heterojunction Solar Cells. Advanced Materials, 27, 2036-2041.

[107] KAAKE, L. G., JASIENIAK, J. J., BAKUS, R. C., WELCH, G. C., MOSES, D., BAZAN, G. C. \& HEEGER, A. J. 2012. Photoinduced Charge Generation in a Molecular Bulk Heterojunction Material. Journal of the American Chemical Society, 134, 19828-19838.

[108] KAAKE, L. G., MOSES, D. \& HEEGER, A. J. 2015. Charge transfer from delocalized excited states in a bulk heterojunction material. Physical Review B, 91, 075436.

[109] BARTELT, J. A., LAM, D., BURKE, T. M., SWEETNAM, S. M. \& MCGEHEE, M. D. 2015. Charge-Carrier Mobility Requirements for Bulk Heterojunction Solar Cells with High Fill Factor and External Quantum Efficiency $>90 \%$. Advanced Energy Materials, 5, 1500577.

[110] SANO, H. \& TACHIYA, M. 1979. Partially diffusion - controlled recombination. The Journal of Chemical Physics, 71, 1276-1282.

[111] TACHIYA, M. \& SEKI, K. 2010. Theory of bulk electron-hole recombination in a medium with energetic disorder. Physical Review B, 82, 085201.

[112] WANG, Z. S., SHA, W. E. I. \& CHOY, W. C. H. 2016. Exciton delocalization incorporated drift-diffusion model for bulk-heterojunction organic solar cells. Journal of Applied Physics, 120, 213101.

[113] JUŠKA, G., ARLAUSKAS, K., STUCHLIK, J. \& ÖSTERBACKA, R. 2006. NonLangevin bimolecular recombination in low-mobility materials. Journal of NonCrystalline Solids, 352, 1167-1171.

[114] PIVRIKAS, A., JUŠKA, G., MOZER, A. J., SCHARBER, M., ARLAUSKAS, K., SARICIFTCI, N. S., STUBB, H. \& ÖSTERBACKA, R. 2005. Bimolecular 
Recombination Coefficient as a Sensitive Testing Parameter for Low-Mobility SolarCell Materials. Physical Review Letters, 94, 176806.

[115] KOSTER, L. J. A., MIHAILETCHI, V. D. \& BLOM, P. W. M. 2006. Bimolecular recombination in polymer/fullerene bulk heterojunction solar cells. Applied Physics Letters, 88, 052104.

[116] DEIBEL, C., WAGENPFAHL, A. \& DYAKONOV, V. 2009. Origin of reduced polaron recombination in organic semiconductor devices. Physical Review B, 80, 075203.

[117] HEIBER, M. C., BAUMBACH, C., DYAKONOV, V. \& DEIBEL, C. 2015. EncounterLimited Charge-Carrier Recombination in Phase-Separated Organic Semiconductor Blends. Physical Review Letters, 114, 136602.

[118] HEIBER, M. C., NGUYEN, T.-Q. \& DEIBEL, C. 2016. Charge carrier concentration dependence of encounter-limited bimolecular recombination in phase-separated organic semiconductor blends. Physical Review B, 93, 205204.

[119] WETZELAER, G. A. H., KUIK, M., NICOLAI, H. T. \& BLOM, P. W. M. 2011. Trapassisted and Langevin-type recombination in organic light-emitting diodes. Physical Review B, 83, 165204.

[120] BUXTON, G. A. \& CLARKE, N. 2006. Predicting structure and property relations in polymeric photovoltaic devices. Physical Review B, 74, 085207.

[121] WILLIAMS, J. \& WALKER, A. B. 2008. Two-dimensional simulations of bulk heterojunction solar cell characteristics. Nanotechnology, 19, 424011.

[122] RAY, B., NAIR, P. R. \& ALAM, M. A. 2011. Annealing dependent performance of organic bulk-heterojunction solar cells: A theoretical perspective. Solar Energy Materials and Solar Cells, 95, 3287-3294.

[123] BLAKESLEY, J. C. \& NEHER, D. 2011. Relationship between energetic disorder and open-circuit voltage in bulk heterojunction organic solar cells. Physical Review B, 84, 075210.

[124] KIRCHARTZ, T., PIETERS, B. E., KIRKPATRICK, J., RAU, U. \& NELSON, J. 2011. Recombination via tail states in polythiophene:fullerene solar cells. Physical Review B, 83, 115209.

[125] FINCK, B. Y. \& SCHWARTZ, B. J. 2016. Drift-Diffusion Studies of Compositional Morphology in Bulk Heterojunctions: The Role of the Mixed Phase in Photovoltaic Performance. Physical Review Applied, 6, 054008.

[126] RAY, B. \& ALAM, M. A. 2012. Random vs regularized OPV: Limits of performance gain of organic bulk heterojunction solar cells by morphology engineering. Solar Energy Materials and Solar Cells, 99, 204-212.

[127] KOSTER, L. J. A., STENZEL, O., OOSTERHOUT, S. D., WIENK, M. M., SCHMIDT, V. \& JANSSEN, R. A. J. 2013. Morphology and Efficiency: The Case of Polymer/ZnO Solar Cells. Advanced Energy Materials, 3, 615-621.

[128] SHAH, M. \& GANESAN, V. 2010. Correlations between Morphologies and Photovoltaic Properties of Rod-Coil Block Copolymers. Macromolecules, 43, 543-552.

[129] STELZL, F. F. \& WÜRFEL, U. 2012. Modeling the influence of doping on the performance of bulk heterojunction organic solar cells: One-dimensional effective semiconductor versus two-dimensional donor/acceptor model. Physical Review B, 86, 075315.

[130] MARTIN, C. M., BURLAKOV, V. M., ASSENDER, H. E. \& BARKHOUSE, D. A. R. 2007. A numerical model for explaining the role of the interface morphology in composite solar cells. Journal of Applied Physics, 102, 104506.

[131] CAHN, J. W. 1965. Phase Separation by Spinodal Decomposition in Isotropic Systems. The Journal of Chemical Physics, 42, 93-99. 
[132] JONES, M. L., DYER, R., CLARKE, N. \& GROVES, C. 2014. Are hot charge transfer states the primary cause of efficient free-charge generation in polymer:fullerene organic photovoltaic devices? A kinetic Monte Carlo study. Physical Chemistry Chemical Physics, 16, 20310-20320.

[133] MATUROVÁ, K., VAN BAVEL, S. S., WIENK, M. M., JANSSEN, R. A. J. \& KEMERINK, M. 2009. Morphological Device Model for Organic Bulk Heterojunction Solar Cells. Nano Letters, 9, 3032-3037.

[134] MATUROVÁ, K., VAN BAVEL, S. S., WIENK, M. M., JANSSEN, R. A. J. \& KEMERINK, M. 2011. Description of the Morphology Dependent Charge Transport and Performance of Polymer:Fullerene Bulk Heterojunction Solar Cells. Advanced Functional Materials, 21, 261-269.

[135] LENES, M., KOSTER, L. J. A., MIHAiletCHI, V. D. \& BLOM, P. W. M. 2006. Thickness dependence of the efficiency of polymer:fullerene bulk heterojunction solar cells. Applied Physics Letters, 88, 243502.

[136] MANDOC, M. M., VEURMAN, W., KOSTER, L. J. A., DE BOER, B. \& BLOM, P. W. M. 2007. Origin of the Reduced Fill Factor and Photocurrent in MDMOPPV:PCNEPV All-Polymer Solar Cells. Advanced Functional Materials, 17, 21672173

[137] KUIK, M., NICOLAI, H. T., LENES, M., WETZELAER, G.-J. A. H., LU, M. \& BLOM, P. W. M. 2011. Determination of the trap-assisted recombination strength in polymer light emitting diodes. Applied Physics Letters, 98, 093301.

[138] MAUER, R., HOWARD, I. A. \& LAQUAI, F. 2010. Effect of Nongeminate Recombination on Fill Factor in Polythiophene/Methanofullerene Organic Solar Cells. The Journal of Physical Chemistry Letters, 1, 3500-3505.

[139] VAN DER KAAP, N. J. \& KOSTER, L. J. A. 2016. Charge carrier thermalization in organic diodes. Scientific Reports, 6, 19794.

[140] MELIANAS, A., PRANCULIS, V., DEVIŽIS, A., GULBINAS, V., INGANÄS, O. \& KEMERINK, M. 2014. Dispersion-Dominated Photocurrent in Polymer:Fullerene Solar Cells. Advanced Functional Materials, 24, 4507-4514.

[141] MELIANAS, A., ETZOLD, F., SAVENIJE, T. J., LAQUAI, F., INGANÄS, O. \& KEMERINK, M. 2015. Photo-generated carriers lose energy during extraction from polymer-fullerene solar cells. Nature Communications, 6, 8778.

[142] LE CORRE, V. M., CHATRI, A. R., DOUMON, N. Y. \& KOSTER, L. J. A. 2017. Charge Carrier Extraction in Organic Solar Cells Governed by Steady-State Mobilities. Advanced Energy Materials, 7, 1701138.

[143] FELEKIDIS, N., MELIANAS, A., AGUIRRE, L. E. \& KEMERINK, M. 2018. Comment on "Charge Carrier Extraction in Organic Solar Cells Governed by SteadyState Mobilities". Advanced Energy Materials, 8, 1800419.

[144] KARUTHEDATH, S., GORENFLOT, J., MELIANAS, A., KAN, Z., KEMERINK, M. \& LAQUAI, F. 2020. Buildup of Triplet-State Population in Operating TQ1:PC71BM Devices Does Not Limit Their Performance. The Journal of Physical Chemistry Letters, $11,2838-2845$.

[145] KHAN, J. I., FIRDAUS, Y., CRUCIANI, F., LIU, S., ANTHOPOULOS, T. D., BEAUJUGE, P. M. \& LAQUAI, F. 2020. Thienyl Sidechain Substitution and Backbone Fluorination of Benzodithiophene-based Donor Polymers Concertedly Minimize Carrier Losses in ITIC-based Organic Solar Cells. The Journal of Physical Chemistry $C$.

[146] KARUTHEDATH, S., MELIANAS, A., KAN, Z., PRANCULIS, V., WOHLFAHRT, M., KHAN, J. I., GORENFLOT, J., XIA, Y., INGANÄS, O., GULBINAS, V., KEMERINK, M. \& LAQUAI, F. 2018. Thermal annealing reduces geminate 
recombination in TQ1:N2200 all-polymer solar cells. Journal of Materials Chemistry $A, 6,7428-7438$.

[147] WÜRFEL, U. \& UNMÜSSIG, M. 2018. Apparent Field-Dependence of the Charge Carrier Generation in Organic Solar Cells as a Result of (Bimolecular) Recombination. Solar RRL, 2, 1800229.

[148] WETZELAER, G.-J. A. H., VAN DER KAAP, N. J., KOSTER, L. J. A. \& BLOM, P. W. M. 2013. Quantifying Bimolecular Recombination in Organic Solar Cells in Steady State. Advanced Energy Materials, 3, 1130-1134.

[149] WHEELER, S., DELEDALLE, F., TOKMOLDIN, N., KIRCHARTZ, T., NELSON, J. \& DURRANT, J. R. 2015. Influence of Surface Recombination on Charge-Carrier Kinetics in Organic Bulk Heterojunction Solar Cells with Nickel Oxide Interlayers. Physical Review Applied, 4, 024020.

[150] KOSTER, L. J. A., MIHAILETCHI, V. D. \& BLOM, P. W. M. 2006. Ultimate efficiency of polymer/fullerene bulk heterojunction solar cells. Applied Physics Letters, $88,093511$.

[151] KOSTER, L. J. A., SHAHEEN, S. E. \& HUMMELEN, J. C. 2012. Pathways to a New Efficiency Regime for Organic Solar Cells. Advanced Energy Materials, 2, 1246-1253.

[152] WÜRFEL, U., NEHER, D., SPIES, A. \& ALBRECHT, S. 2015. Impact of charge transport on current-voltage characteristics and power-conversion efficiency of organic solar cells. Nature Communications, 6, 6951.

[153] KIRCHARTZ, T., TARETTO, K. \& RAU, U. 2009. Efficiency Limits of Organic Bulk Heterojunction Solar Cells. The Journal of Physical Chemistry C, 113, 17958-17966.

[154] SHOCKLEY, W. \& QUEISSER, H. J. 1961. Detailed Balance Limit of Efficiency of p - n Junction Solar Cells. Journal of Applied Physics, 32, 510-519.

[155] RÜHLE, S. 2016. Tabulated values of the Shockley-Queisser limit for single junction solar cells. Solar Energy, 130, 139-147.

[156] AZZOUZI, M., YAN, J., KIRCHARTZ, T., LIU, K., WANG, J., WU, H. \& NELSON, J. 2018. Nonradiative Energy Losses in Bulk-Heterojunction Organic Photovoltaics. Physical Review X, 8, 031055.

[157] JANSSEN, R. A. J. \& NELSON, J. 2013. Factors Limiting Device Efficiency in Organic Photovoltaics. Advanced Materials, 25, 1847-1858.

[158] SCHARBER, M. C. \& SARICIFTCI, N. S. 2013. Efficiency of bulk-heterojunction organic solar cells. Progress in Polymer Science, 38, 1929-1940.

[159] BAUER, N., ZHANG, Q., RECH, J. J., DAI, S., PENG, Z., ADE, H., WANG, J., ZHAN, X. \& YOU, W. 2019. The impact of fluorination on both donor polymer and nonfullerene acceptor: The more fluorine, the merrier. Nano Research, 12, 2400-2405.

[160] LIN, Y., ZHAO, F., PRASAD, S. K. K., CHEN, J.-D., CAI, W., ZHANG, Q., CHEN, K., WU, Y., MA, W., GAO, F., TANG, J.-X., WANG, C., YOU, W., HODGKISS, J. M. \& ZHAN, X. 2018. Balanced Partnership between Donor and Acceptor Components in Nonfullerene Organic Solar Cells with $>12 \%$ Efficiency. Advanced Materials, 30, 1706363.

[161] FAN, Q., SU, W., WANG, Y., GUO, B., JIANG, Y., GUO, X., LIU, F., RUSSELL, T. P., ZHANG, M. \& LI, Y. 2018. Synergistic effect of fluorination on both donor and acceptor materials for high performance non-fullerene polymer solar cells with $13.5 \%$ efficiency. Science China Chemistry, 61, 531-537.

[162] ZHANG, L., ZHAO, H., LIN, B., YUAN, J., XU, X., WU, J., ZHOU, K., GUO, X., ZHANG, M. \& MA, W. 2019. A blade-coated highly efficient thick active layer for non-fullerene organic solar cells. Journal of Materials Chemistry A, 7, 22265-22273.

[163] CHANDRABOSE, S., CHEN, K., BARKER, A. J., SUTTON, J. J., PRASAD, S. K. K., ZHU, J., ZHOU, J., GORDON, K. C., XIE, Z., ZHAN, X. \& HODGKISS, J. M. 2019. 
High Exciton Diffusion Coefficients in Fused Ring Electron Acceptor Films. Journal of the American Chemical Society, 141, 6922-6929. 